\title{
Bis(alkynyl), Metallacyclopentadiene, and Diphenylbutadiyne Complexes of Ruthenium
}

\author{
Anthony F. Hill, ${ }^{*}$ A. David Rae ${ }^{\dagger}$ Madeleine Schultz, ${ }^{\ddagger}$ and Anthony C. Willis \\ Research School of Chemistry, Institute of Advanced Studies, Australian National University, \\ Canberra, Australian Capital Territory, Australia
}

Received September 28, 2006

\begin{abstract}
Heating diphenylbutadiyne with $\left[\mathrm{Ru}(\mathrm{CO})_{2}\left(\mathrm{PPh}_{3}\right)_{3}\right]$ or $\left[\mathrm{Ru}(\mathrm{CO})_{3}\left(\mathrm{PPh}_{3}\right)_{2}\right]$ in toluene under reflux provides respectively the ruthenacyclopentadiene $\left[\mathrm{Ru}\left\{\kappa^{2}-\mathrm{CR}=\mathrm{CPhCPh}=\mathrm{CR}\right\}(\mathrm{CO})_{2}\left(\mathrm{PPh}_{3}\right)_{2}\right](\mathrm{R}=\mathrm{C} \equiv \mathrm{CPh})$ or the cyclopentadienone complex $\left[\mathrm{Ru}\left\{\eta^{4}-\mathrm{O}=\mathrm{CC}_{4} \mathrm{Ph}_{2} \mathrm{R}_{2}\right\}(\mathrm{CO})_{2}\left(\mathrm{PPh}_{3}\right)\right]$, the latter via $[2+2+1]$ alkyne and $\mathrm{CO}$ cyclization. The bis(alkynyl) complex cis, cis, trans- $\left[\mathrm{Ru}(\mathrm{C} \equiv \mathrm{CPh})_{2}(\mathrm{CO})_{2}\left(\mathrm{PPh}_{3}\right)_{2}\right]$ is not formed in either of these reactions but is the product of the reaction of $\left[\mathrm{RuCl}_{2}(\mathrm{CO})_{2}\left(\mathrm{PPh}_{3}\right)_{2}\right]$ with $\mathrm{LiC} \equiv \mathrm{CPh}$ or of cis,$m e r-\left[\mathrm{Ru}(\mathrm{C} \equiv \mathrm{CPh})_{2}(\mathrm{CO})\left(\mathrm{PPh}_{3}\right)_{3}\right]$ with $\mathrm{CO}$. Although the bis(alkynyl) complex does not undergo reductive elimination to provide the diyne complex, thermolysis of cis, cis, trans $-\left[\mathrm{Ru}(\mathrm{C} \equiv \mathrm{CPh})(\mathrm{HgC} \equiv \mathrm{CPh})(\mathrm{CO})_{2^{-}}\right.$ $\left.\left(\mathrm{PPh}_{3}\right)_{2}\right]$ (obtained from $\left[\mathrm{Ru}(\mathrm{CO})_{2}\left(\mathrm{PPh}_{3}\right)_{3}\right]$ and $\left.\left[\mathrm{Hg}(\mathrm{C} \equiv \mathrm{CPh})_{2}\right]\right)$ provides a noninterconvertible 1:1 mixture of cis,cis,trans-[Ru(C $\left.\equiv \mathrm{CPh})_{2}(\mathrm{CO})_{2}\left(\mathrm{PPh}_{3}\right)_{2}\right]$ and $\left[\mathrm{Ru}(\eta-\mathrm{PhC} \equiv \mathrm{CC} \equiv \mathrm{CPh})(\mathrm{CO})_{2}\left(\mathrm{PPh}_{3}\right)_{2}\right]$.
\end{abstract}

\section{Introduction}

We have recently reported a remarkably facile cleavage of the $\mathrm{C}_{\mathrm{sp}}-\mathrm{C}_{\mathrm{sp}}$ bonds of dimetallaoctatetraynes $\left[\mathrm{L}(\mathrm{CO})_{2} \mathrm{~W} \equiv \mathrm{CC} \equiv\right.$ $\left.\mathrm{CC} \equiv \mathrm{CC} \equiv \mathrm{W}(\mathrm{CO})_{2} \mathrm{~L}\right]\left(\mathrm{L}=\mathrm{HB}(\mathrm{pz})_{3}, \mathrm{HB}\left(\mathrm{pzMe}_{2}\right)_{3} ; \mathrm{pz}=\right.$ pyrazolyl) upon reaction with the complex $\left[\mathrm{Ru}(\mathrm{CO})_{2}\left(\mathrm{PPh}_{3}\right)_{3}\right](\mathbf{1})$ to form $\left[\mathrm{Ru}\left\{\mathrm{C} \equiv \mathrm{CC} \equiv \mathrm{W}(\mathrm{CO})_{2} \mathrm{~L}\right\}_{2}(\mathrm{CO})_{2}\left(\mathrm{PPh}_{3}\right)_{2}\right] .{ }^{1}$ The same prod-<smiles></smiles>

(1)<smiles>O=[Po]([O-])([O-])[Pb]([O-])([O-])[PbH]</smiles>

(2) uct is obtained from the reaction of $\mathbf{1}$ with the bis(tricarbido) mercurials $\operatorname{Hg}\left\{\mathrm{C} \equiv \mathrm{CC} \equiv \mathrm{W}(\mathrm{CO})_{2} \mathrm{~L}\right\}_{2}$, via simple $\pi$ adducts of the dimetallaoctatetraynes with mercury extrusion. ${ }^{1}$ These somewhat surprising results have led us to now revisit the reaction of 1 with the simpler reagent $\mathrm{PhC} \equiv \mathrm{CC} \equiv \mathrm{CPh}^{2}$ and to investigate the reactions of $\mathbf{1}$ with $\mathrm{Hg}(\mathrm{C} \equiv \mathrm{CPh})_{2}$ in the hope of shedding light upon the curious mechanistic aspects. The reactions of $\left[\mathrm{Ru}(\mathrm{CO})_{2}\left(\mathrm{PPh}_{3}\right)_{2}(\mathrm{~L})\right]\left(\mathrm{L}=\mathrm{PPh}_{3}(\mathbf{1}), \mathrm{CO}(\mathbf{2})\right)$ with diphenylacetylene in refluxing toluene are markedly dependent on the ligand "L". ${ }^{3}$ Thus for $\mathbf{1}$, which has one labile phosphine, a complex of 2-phenylindenone results, $\left[\mathrm{Ru}\left(\eta^{4}-\mathrm{O}=\mathrm{CCPhCHC}_{6} \mathrm{H}_{4}\right)\right.$ $\left.(\mathrm{CO})\left(\mathrm{PPh}_{3}\right)_{2}\right]$ (3), via the intermediacy of the previously reported ${ }^{4}$ alkyne complex $\left[\mathrm{Ru}(\eta-\mathrm{PhC} \equiv \mathrm{CPh})(\mathrm{CO})_{2}\left(\mathrm{PPh}_{3}\right)_{2}\right](\mathbf{4 a})$. In contrast, for complex 2 , the tetraphenylcyclopentadienone complex $\left[\mathrm{Ru}\left(\eta^{4}-\mathrm{O}=\mathrm{CC}_{4} \mathrm{Ph}_{4}\right)(\mathrm{CO})_{2}\left(\mathrm{PPh}_{3}\right)\right](5)$ is obtained, while

\footnotetext{
* To whom correspondence should be addresed: E-mail: a.hill@ anu.edu.au.

E-mail for crystallographic enquiries: rae@rsc.anu.edu.au.

$\uparrow$ Current address: School of Molecular and Microbial Sciences, University of Queensland, St Lucia, Australia 4072.

(1) Dewhurst, R. D.; Hill, A. F.; Rae, A. D.; Willis, A. C. Organometallics 2005, 24, 4703.

(2) Alcock, N. W.; Hill, A. F.; Melling, R. P.; Thompsett, A. R. Organometallics 1993, 12, 641.

(3) Hill, A. F.; Schultz, M.; Willis, A. C. Organometallics 2004, 23, 5729.

(4) Cavit, B. E.; Grundy, K. R.; Roper, W. R. J. Chem. Soc., Chem. Commun. 1972, 60 .
}

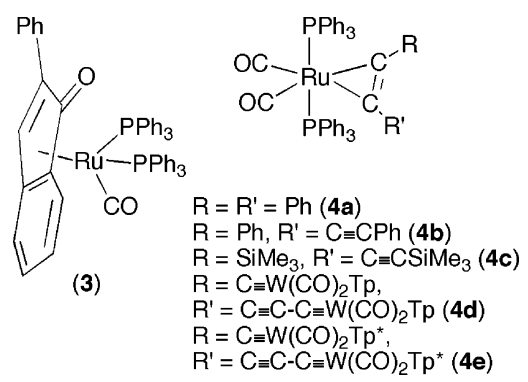

the cyclopentadienone complex $\left[\mathrm{Ru}\left\{\kappa^{1}-S: \eta^{4}-\mathrm{O}=\mathrm{C}\left(\mathrm{CMe}=\mathrm{CSC}_{2-}\right.\right.\right.$ $\left.\left.\left.\mathrm{H}_{4}\right)_{2} \mathrm{~S}\right\}(\mathrm{CO})\left(\mathrm{PPh}_{3}\right)\right](\mathbf{6})$ is obtained from the reaction of $\mathbf{1}$ with 4,7,10-trithiatrideca-2,11-diyne. ${ }^{5}$ We have previously reported

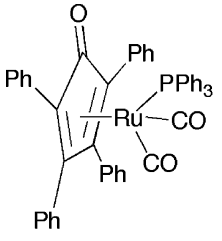

(5)

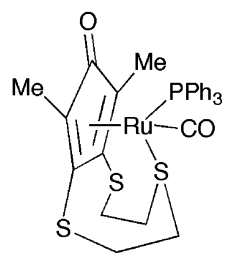

(6) the synthesis of the diyne complex $[\mathrm{Ru}(\eta-\mathrm{PhC} \equiv \mathrm{CC} \equiv \mathrm{CPh})$ $(\mathrm{CO})_{2}\left(\mathrm{PPh}_{3}\right)_{2}$ ] (4b) via phosphine substitution with $\mathbf{1 .}^{2}$ In the interim it has been reported that $\mathbf{2}$ does not react with alkynes in refluxing toluene. It was claimed, however, that $\mathbf{2}$ could be activated toward alkyne coupling processes by carbon dioxide via the proposed intermediate salts cis- and trans- $\left[\mathrm{Ru}(\mathrm{CO})_{4}{ }^{-}\right.$ $\left.\left(\mathrm{PPh}_{3}\right)_{2}\right]\left[\mathrm{O}_{2} \mathrm{CO}\right](7)$ and isolated carbonato complex $\left[\mathrm{Ru}\left(\mathrm{O}_{2^{-}}\right.\right.$ $\left.\mathrm{CO})(\mathrm{CO})_{2}\left(\mathrm{PPh}_{3}\right)_{2}\right](\mathbf{8})^{6}$ (reported previously from the reaction of 2 with air). ${ }^{8}$ This complex was, however, not formed from 2 and $\mathrm{CO}_{2}$ in the absence of alkynes. ${ }^{6}$ Regarding the existence of the proposed carbonate salt 7, we note that Hieber has reported

(5) Hill, A. F.; Rae, A. D.; Schultz, M.; Willis, A. C. Organometallics 2004, 23, 81 .

(6) Yamazaki, H.; Taira, Z. J. Organomet. Chem. 1999, 578, 61

(7) Hieber, W.; Frey, V.; John, P. Chem. Ber. 1967, 100, 1961.

(8) Valentine, J.; Valentine, D. Jr.; Collman, J. P. Inorg. Chem. 1971, $10,219$. 


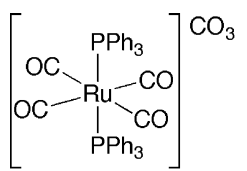

(7)

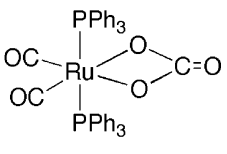

(8) the synthesis of the salt $\left[\mathrm{Os}(\mathrm{CO})_{4}\left(\mathrm{PPh}_{3}\right)_{2}\right]\left[\mathrm{AlCl}_{4}\right]_{2}$ from $\mathrm{Al}_{2}$ $\mathrm{Cl}_{6}, \mathrm{CO}\left(300 \mathrm{~atm}, 100{ }^{\circ} \mathrm{C}\right)$ and $\left[\mathrm{OsCl}_{2}(\mathrm{CO})_{2}\left(\mathrm{PPh}_{3}\right)_{2}\right]$ but that the reaction stops for ruthenium at $\left[\mathrm{RuCl}(\mathrm{CO})_{3}\left(\mathrm{PPh}_{3}\right)_{2}\right]\left[\mathrm{AlCl}_{4}\right]$. Both species are exceedingly reactive toward oxygen nucleophiles, making a carbonate salt implausible. We have since shown that $\mathrm{CO}_{2}$ is not required for the thermal reaction of $\mathbf{2}$ (or 1) with diphenylacetylene, ${ }^{3}$ and since the diyne complex 4b seemed a plausible mechanistic candidate for an intermediate in the reactions of 2 with $\mathrm{PhC} \equiv \mathrm{CC}=\mathrm{CPh}$, we have now investigated these reactions in detail and can clarify, at least to a degree, the apparently disparate results in the literature.

\section{Results and Discussion}

Given the centrality of diyne coordination to the results that follow and the scarcity of structural data for mononuclear diyne complexes of group 8 metals (one previous example on iron), we have now structurally characterized the key complex $\mathbf{4 b}$ as a benzene monosolvate. The gross results of this study are summarized in Figure 1; however, it should be noted that the solution involved a considerable amount of nonstandard modeling due to the 50:50 positional disorder of the majority of the phenyl rings in the molecule (see Experimental Section). The general coordination and structural chemistry of di- and polyynes has been reviewed recently, ${ }^{9}$ and crystallographic data ${ }^{9-11}$ for 20 mononuclear diyne complexes in addition to those for $\mathbf{4 b}$ have been tabulated (Table 1), from which it can be seen that the ratios of bond lengths for the coordinated and free $\mathrm{C} \equiv \mathrm{C}$ bonds fall in the range 1.051-1.151: i.e., a coordinative lengthening of $5-15 \%$.

The anomalous example in this list is Berke's complex [Fe$\left.\left(\eta-\mathrm{Me}_{3} \mathrm{SiC} \equiv \mathrm{CC} \equiv \mathrm{CSiMe}_{3}\right)(\mathrm{CO})_{2}\left(\mathrm{PEt}_{3}\right)_{2}\right](1.031),{ }^{11 \mathrm{r}}$ which of all the complexes is most akin to $\mathbf{4 b}$. The modest lengthening of the coordinated $\mathrm{C} \equiv \mathrm{C}$ bond length relative to the uncoordinated alkyne moietry seen for this iron complex is noteworthy in that one might expect significant retrodonation from the $\pi$-basic iron center. In a similar manner the $6 \%$ lengthening observed for

(9) Low, P. J.; Bruce, M. I. Adv. Organomet. Chem. 2002, 48, 71.

(10) Conquest; Cambridge Crystallographic Data Centre, Release May 2006.

(11) (a) Pelling, P.-M.; Kirchbauer, F. G.; Burlakov, U. U.; Baumann, W.; Spannenburg, A. J. Am. Chem. Soc. 1999, 121, 8313. (b) Stahl, K.; Weller, F.; Dehnicke, K. Z. Anorg. Allg. Chem. 1984, 518, 175. (c) Rupp, R.; Huttner, G.; Lang, H.; Heinze, K.; Buchner, M.; Hoverstreydt, E. R. Eur. J. Inorg. Chem. 2000, 1953. (d) Bonrath, W.; Porschke, K. R.; Wilke, G.; Angermund, K.; Kruger, C. Angew. Chem., Int. Ed. Engl. 1988, 27, 833. (e) Castellano, B.; Solani, E.; Floriani, C.; Re, N.; Chiesi-Villa, A.; Rizzoli, C. Chem., Eur. J. 1999, 5, 722. (f) Rapport, T.; Burnberg, O.; Werner, H. Organometallics 1993, 12, 1359. (g) Garcia-Yebra, C.; Carrero, F.; Lopez-Mardomingo, C.; Fajardo, M.; Rodriguez, A.; Antinolo, A.; Otero, A.; Lucas, D.; Mugnier, Y, Organometallics 1999, 18, 1287 (h) Yamazaki, S.; Deeming, A. J.; Speel, D. S. Organometallics 1998, 17, 775. (i) Choukroun, R.; Zhao, J.; lrober, C.; Cassoux, P.; Donnadieu, B. Chem. Commun. 2000, 1151. (j) Ursini, C. V.; Dias, G. H. M.; Horner, M.; Bortoluzzi, A. J.; Morigaki, M. K. Polyhedron 2000, 19, 2261. (k) Gauss, C.; Veghini, D.; Berke, H. Chem. Ber. 1997, 130, 183. (1) Werth, A.; Dehnicke, K.; Fenske, D.; Baum, G. Z. Anorg. Allg. Chem. 1990, 591, 125 (m) Werner, H.; Gevert, O.; Haquette, P. Organometallics 1997, 16, 803. (n) Chen, J.; Guzei, I. A.; Woo, L. K. Inorg. Chem. 2000, 39, 3715. (o) Rosenthal, U.; Pulst, S.; Arndt, P.; Baumann, W.; Tillack, A.; Kempe, R. Z. Naturforsch. 1995, 50b, 368. (p) Rosenthal, U.; Pulst, S.; Arndt, P.; Baumann, W.; Tillack, A.; Kempe, R. Z. Naturforsch. 1995, 50b, 377. (q) Rodewald, D.; Schulzke, C.; Rehder, D. J. Organomet. Chem. 1995, 498, 291. (r) Gauss, C.; Veghini, D.; Berke, H. Chem. Ber. 1997, 130, 183.

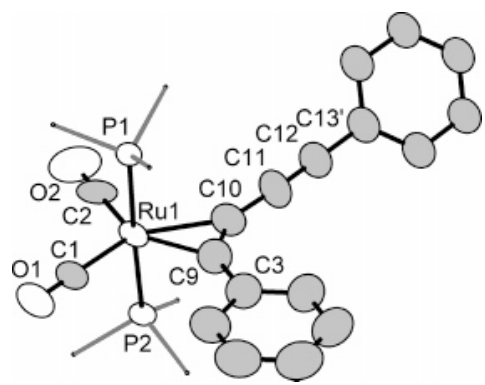

Figure 1. Molecular geometry of $\mathbf{4 b}$ in the crystal of $\mathbf{4 b} \cdot \mathrm{C}_{6} \mathrm{H}_{6}$ (50\% displacement ellipsoids, phosphine phenyl groups and hydrogen atoms omitted). Selected bond lengths $(\AA)$ and angles $(\mathrm{deg}): \mathrm{Ru} 1-\mathrm{P} 1=2.375(2), \mathrm{Ru} 1-\mathrm{P} 2=2.388(2), \mathrm{Ru} 1-\mathrm{C} 9=$ $2.119(7), \mathrm{Ru} 1-\mathrm{C} 10=2.145(6), \mathrm{C} 3-\mathrm{C} 9=1.442(9), \mathrm{C} 9-\mathrm{C} 10=$ $1.305(9), \mathrm{C} 10-\mathrm{C} 11=1.383(9), \mathrm{C} 11-\mathrm{C} 12=1.226(9), \mathrm{C} 12-\mathrm{C} 13$ $=1.415(9) ; \mathrm{P} 1-\mathrm{Ru} 1-\mathrm{P} 2=177.9(1), \mathrm{C} 1-\mathrm{Ru} 1-\mathrm{C} 2=106.9(3)$, $\mathrm{C} 9-\mathrm{Ru} 1-\mathrm{C} 10=35.6(2), \mathrm{Ru} 1-\mathrm{C} 1-\mathrm{O} 1=178.7(5), \mathrm{Ru} 1-\mathrm{C} 2-$ $\mathrm{O} 2=178.2(6), \mathrm{Ru} 1-\mathrm{C} 9-\mathrm{C} 3=147.3(4), \mathrm{Ru} 1-\mathrm{C} 9-\mathrm{C} 10=73.3-$ (4), $\mathrm{Ru} 1-\mathrm{C} 10-\mathrm{C} 9=71.1(4), \mathrm{Ru} 1-\mathrm{C} 10-\mathrm{C} 11=145.5(5), \mathrm{C} 3-$ $\mathrm{C} 9-\mathrm{C} 10=139.4(6), \mathrm{C} 9-\mathrm{C} 10-\mathrm{C} 11=143.3(7), \mathrm{C} 10-\mathrm{C} 11-\mathrm{C} 12$ $=177.4(7), \mathrm{C} 11-\mathrm{C} 12-\mathrm{C} 13=170.0(5)$. The diagram depicts one of two disordered orientations for the alkynyl phenyl ring based on $\mathrm{C} 13^{\prime}$.

Table 1. Structural Data for Mononuclear 1,3-Diyne Complexes ${ }^{10,11}$

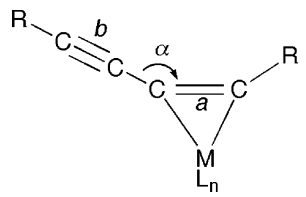

\begin{tabular}{|c|c|c|c|c|}
\hline complex & $a, \AA$ & $b, \AA$ & $a / b, \AA$ & $\alpha, \operatorname{deg}$ \\
\hline$\left[\mathrm{Fe}\left(\mathrm{Me}_{3} \mathrm{SiC}_{4} \mathrm{SiMe}_{3}\right)(\mathrm{CO})_{2}\left(\mathrm{PEt}_{3}\right)_{2}\right]$ & 1.251 & 1.213 & 1.031 & 150.0 \\
\hline$\left[\mathrm{Rh}\left(\mathrm{PhC}_{4} \mathrm{Ph}\right) \mathrm{Br}\left(\mathrm{P}^{\mathrm{i}} \mathrm{Pr}_{3}\right)_{2}\right]$ & 1.260 & 1.199 & 1.051 & 158.5 \\
\hline$\left[\mathrm{Rh}_{(}\left(\mathrm{Me}_{3} \mathrm{SiC}_{4} \mathrm{SiMe}_{3}\right) \mathrm{Cl}\left(\mathrm{PiPr}_{3}\right)_{2}\right]$ & 1.261 & 1.192 & 1.058 & 156 \\
\hline$\left[\mathrm{Ni}\left(\mathrm{Me}_{3} \mathrm{SiC}_{4} \mathrm{SiMe}_{3}\right)\left(\mathrm{PPh}_{3}\right)_{2}\right]$ & 1.289 & 1.212 & 1.064 & 148.0 \\
\hline$\left[\mathrm{Ru}\left(\mathrm{PhC}_{4} \mathrm{Ph}\right)(\mathrm{CO})_{2}\left(\mathrm{PPh}_{3}\right)_{2}\right]$ & 1.305 & 1.226 & 1.064 & 143.3 \\
\hline$\left[\mathrm{Ni}\left({ }^{(} \mathrm{BuC}_{4}{ }_{4}^{\mathrm{B}} \mathrm{Bu}\right)\left\{\mathrm{P}(o-\text { tolyl })_{3}\right\}_{2}\right]$ & 1.268 & 1.186 & 1.069 & 144.5 \\
\hline$\left[\mathrm{Nb}\left(\mathrm{PhC}{ }_{4} \mathrm{Ph}\right) \mathrm{Cl}\left(\mathrm{C}_{5} \mathrm{H}_{4} \mathrm{SiMe}_{3}\right)_{2}\right]^{a}$ & 1.278 & 1.193 & 1.071 & 144.2 \\
\hline$\left[\mathrm{Ni}\left(\mathrm{PhC}_{4} \mathrm{Ph}\right)\left(\mathrm{PPh}_{3}\right)_{2}\right]$ & 1.286 & 1.197 & 1.074 & 151.3 \\
\hline$\left[\mathrm{Ni}\left(\mathrm{HC}_{4} \mathrm{CH}\right)\left\{\left({ }^{\mathrm{i}} \mathrm{Pr}_{2} \mathrm{PCH}_{2}\right)_{2} \mathrm{CH}_{2}\right\}\right]$ & 1.280 & 1.191 & 1.075 & 146.2 \\
\hline$\left[\mathrm{Ni}\left(\mathrm{BBCC}_{4}^{\mathrm{t}} \mathrm{Bu}\right)\left(\mathrm{PPh}_{3}\right)_{2}\right]$ & 1.279 & 1.189 & 1.076 & 149.4 \\
\hline$\left[\mathrm{Ti}\left(\mathrm{PhC}_{4} \mathrm{Ph}\right)\left(\mathrm{C}_{5} \mathrm{Me}_{5}\right)_{2}\right]$ & 1.312 & 1.214 & 1.081 & 141.9 \\
\hline$\left[\mathrm{Pt}\left(\mathrm{PhC}_{4} \mathrm{Ph}\right)\left(\mathrm{PPh}_{3}\right)_{2}\right]$ & 1.305 & 1.200 & 1.088 & 146.7 \\
\hline$\left[\mathrm{Ti}\left(\mathrm{PhC}_{4} \mathrm{Ph}\right)(\mathrm{TTP})\right]^{c}$ & 1.316 & 1.210 & 1.088 & 140.5 \\
\hline$\left[\mathrm{Ni}\left({ }^{\mathrm{B}} \mathrm{BuC} \mathrm{C}_{4}{ }^{\mathrm{t}} \mathrm{Bu}\right)(\mathrm{bipy})\right]$ & 1.288 & 1.184 & 1.088 & 152.3 \\
\hline$\left[\mathrm{W}\left(\mathrm{PhC}_{4} \mathrm{SiMe}_{3}\right) \mathrm{F}_{5} \mathrm{Na}\left([16] \mathrm{aneO}_{5}\right.\right.$ & 1.307 & 1.201 & 1.089 & 142.1 \\
\hline$\left[\mathrm{Co}\left({ }^{(} \mathrm{BuC}_{4}{ }^{ } \mathrm{Bu}\right)\left\{\mathrm{Ph}_{2} \mathrm{PCH}_{2}\right) \mathrm{CMe}\right] \mathrm{PF}$ & 1.313 & 1.200 & 1.094 & 140.0 \\
\hline$\left.\left[\mathrm{Pt}\left(\mathrm{PhC}_{4} \mathrm{Ph}\right)\left\{\mathrm{Ph}_{2} \mathrm{PC}_{5} \mathrm{H}_{4}\right)_{2} \mathrm{Fe}\right\}\right]$ & 1.293 & 1.176 & 1.099 & 147.0 \\
\hline$\left[\mathrm{Zr}\left(\mathrm{PhC}_{4} \mathrm{Ph}\right)(\mathrm{CCPh})\left(\mathrm{C}_{5} \mathrm{H}_{5}\right)_{2} \mathrm{Li}(\mathrm{thf})_{2}\right]$ & 1.336 & 1.210 & 1.104 & 127.8 \\
\hline$\left[\mathrm{Nb}\left(\mathrm{MeC}_{4} \mathrm{Me}\right) \mathrm{I}(\mathrm{CO})_{2}\left(\mathrm{PEt}_{3}\right)_{2}\right]$ & 1.341 & 1.192 & 1.125 & 138.1 \\
\hline$\left[\mathrm{W}\left(\mathrm{PhC}_{4} \mathrm{Ph}\right) \mathrm{Cl}_{5}\right]\left[\mathrm{PPh}_{4}\right]$ & 1.326 & 1.161 & 1.142 & 149.6 \\
\hline$\left[\mathrm{Ta}(\mathrm{PhC} 4 \mathrm{Ph})(\mathrm{CCPh})(\right.$ calix $) \mathrm{LiOEt}_{2}$ & 1.386 & 1.204 & 1.151 & 130.8 \\
\hline
\end{tabular}

${ }^{a}$ Average of two crystallographically independent molecules. ${ }^{b}$ calix $=$ calix[4]arene tetranion. ${ }^{c}$ TTP $=$ tetraphenylporphyrinate dianion.

4b is also relatively small $(\mathrm{C} 9-\mathrm{C} 10=1.305(9) \AA)$, although somewhat greater than that observed for the simple alkyne complex $\left[\mathrm{Ru}(\eta-\mathrm{PhC} \equiv \mathrm{CPh})(\mathrm{CO})_{2}\left(\mathrm{PPh}_{3}\right)_{2}\right](1.274(3) \AA)^{3}{ }^{3}$ The equatorial sites of a $\mathrm{d}^{8}$ trigonal bipyramid are generally considered to be the more strongly $\pi$ basic; however, in the case of $\mathbf{4 b}$ and the other anomalous complex discussed above, the two carbonyl ligands compete for the metal's retrodative capacity, an interpretation that would account for the modest lengthening of the alkyne upon coordination. Notably, for potent $\pi$-acids coordinated to the " $\mathrm{Ru}(\mathrm{CO})_{2}\left(\mathrm{PPh}_{3}\right)_{2}$ " fragment, an alternative geometry with cis-equatorial phosphines has been observed: e.g., in the tetrafluoroethene complex $\left[\mathrm{Ru}\left(\eta-\mathrm{C}_{2} \mathrm{~F}_{4}\right)-\right.$ 
$\left.(\mathrm{CO})_{2}\left(\mathrm{PPh}_{3}\right)_{2}\right] .{ }^{12}$ That the coordinated $\mathrm{C} \equiv \mathrm{C}$ bond of $\mathbf{4 b}$ is longer than that of $\mathbf{4 a}$ might be traced to the electron-withdrawing nature of the alkynyl substituent, increasing retrodonation. This is supported by the increase in the frequency and force constant of the carbonyl associated infrared absorptions (4a, $v_{\text {CO }} 1962$, $1892 \mathrm{~cm}^{-1}, k_{\mathrm{CO}}=15.00 \mathrm{~N} \mathrm{~cm}^{-1} ; \mathbf{4 b}, v_{\mathrm{CO}} 1971,1908 \mathrm{~cm}^{-1}$, $k_{\mathrm{CO}}=15.19 \mathrm{~N} \mathrm{~cm}^{-1}$ ).

Heating 1 with excess diphenylbutadiyne (toluene, reflux) leads to immediate formation of $\mathbf{4 b}$, followed by the slow (12$14 \mathrm{~h}$ ) formation of a new compound, $\mathbf{9}$, which gives rise to two new $v_{\mathrm{CO}}$ bands $\left(2017,1960 \mathrm{~cm}^{-1}\right)$, in addition to an alkynyl band at $2151 \mathrm{~cm}^{-1}$ (toluene solution). A further structured

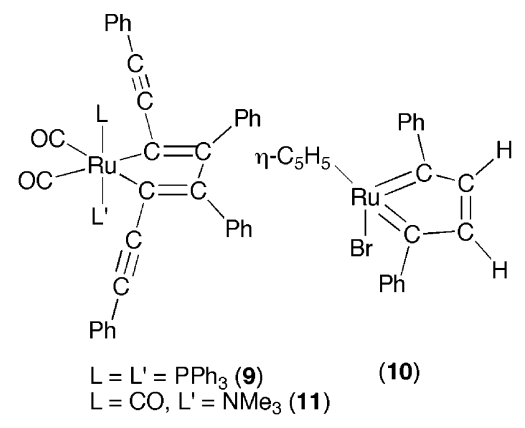<smiles></smiles>

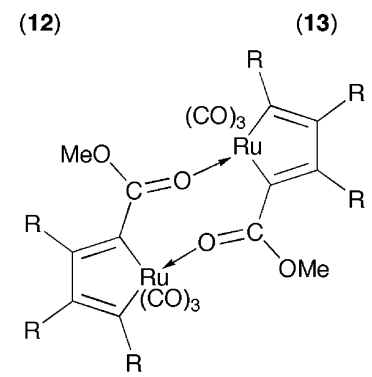

$\mathrm{R}=\mathrm{CO}_{2} \mathrm{Et}(\mathbf{1 4})$

absorption also develops in the range 1600-1595 $\mathrm{cm}^{-1}$; however, this could not be unequivocally assigned to the coordinated alkyne, due to the aryl bands also appearing in this region. The change in color from yellow to dark orange is accompanied by the replacement of the original ${ }^{31} \mathrm{P}\left\{{ }^{1} \mathrm{H}\right\}$ NMR singlet due to $\mathbf{1}\left(\delta_{\mathrm{P}} 50.9\right)$ with that of $\mathbf{4 b}\left(\delta_{\mathrm{P}} 43.7\right)$ and finally with a new signal at $\delta_{\mathrm{P}} 36.4$. In refluxing xylene, the reaction is complete in $10 \mathrm{~min}$, giving the same product. The same spectroscopic changes are seen when preisolated $\mathbf{4 b}$ is heated in the presence of excess $\mathrm{PhC} \equiv \mathrm{CC} \equiv \mathrm{CPh}$. When $\mathbf{4 b}$ was heated in $d_{8}$-toluene in the absence of additional diyne, after overnight reflux the resonance due to $\mathbf{4 b}$ had decreased, being replaced by a major resonance due to $\left[\mathrm{Ru}(\mathrm{CO})_{3}\left(\mathrm{PPh}_{3}\right)_{2}\right]\left(2 ; \delta_{\mathrm{P}} 57.1\right)$, which may be accounted for by dissociation of the alkyne ligand from $\mathbf{4 b}$. Smaller resonances were observed at $\delta_{\mathrm{P}} 51.3,51.2$, 50.2, 46.7, 38.2, 36.4 (9, vide infra), $25.5\left(\mathrm{OPPh}_{3}\right)$, and -4.1 $\left(\mathrm{PPh}_{3}\right)$. After 2 days at reflux, an additional resonance at $\delta_{\mathrm{P}}$ 45.2 was observed; the components were all present in approximately equal amounts, although slightly more of $\mathbf{4 b}$ and

(12) Burrell, A. K.; Clark, G. R.; Rickard, C. E. F.; Roper, W. R.; Ware, D. C., J. Organomet. Chem. 1990, 398, 133.
Scheme 1. Reactions of 1 and 2 with Diphenylbutadiyne $\left(\mathbf{L}=\mathbf{P P h}_{3}\right)$

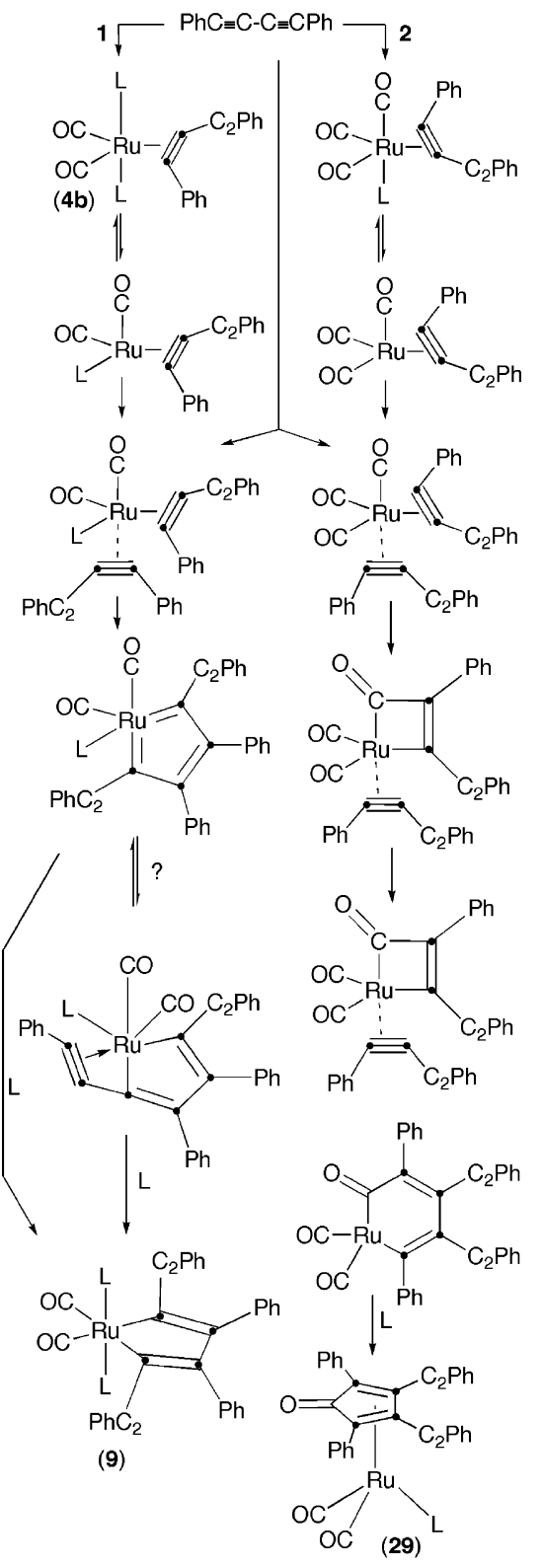

the component at $\delta_{\mathrm{P}} 38.2$ were present. Further heating did not change the composition of the mixture, and no tractable product could be isolated. Reflux of $\mathbf{4 b}$ in the lower boiling $\mathrm{C}_{6} \mathrm{D}_{6}$ resulted in a similar mixture, with an additional resonance at $\delta_{\mathrm{P}}$ 33.7. Thus, it appears that further diyne is required for the clean formation of $\mathbf{9}$ and that the small amount of $\mathbf{9}$ formed in the absence of added diyne can be accounted for by ligand scrambling in $\mathbf{4 b}$. Within this manifold of reagents, 2 appears to be particularly stable and generally accumulates in such ligand scrambling reactions.

The presence of a cis-/trans-" $\mathrm{Ru}$ II $(\mathrm{CO})_{2}\left(\mathrm{PPh}_{3}\right)_{2}$ " group straddling a molecular plane of symmetry in the complex 9 was deduced from a combination of spectroscopic data (two $v(\mathrm{CO})$ absorptions, one ${ }^{13} \mathrm{C}\left\{{ }^{1} \mathrm{H}\right\}$ carbonyl resonance, a single ${ }^{31} \mathrm{P}\left\{{ }^{1} \mathrm{H}\right\}$ NMR resonance, and virtual triplet structure for $\mathrm{PC}_{6} \mathrm{H}_{5}{ }^{13} \mathrm{C}$ $\left\{{ }^{1} \mathrm{H}\right\}$ NMR signals). The nature of the organic ligand(s) occupying the remaining two sites did not, however, follow unambiguously from spectroscopic data, due in part to the complexity of the aromatic regions of the ${ }^{13} \mathrm{C}\left\{{ }^{1} \mathrm{H}\right\}$ and ${ }^{1} \mathrm{H}$ NMR spectra. The identity of the product was eventually established 


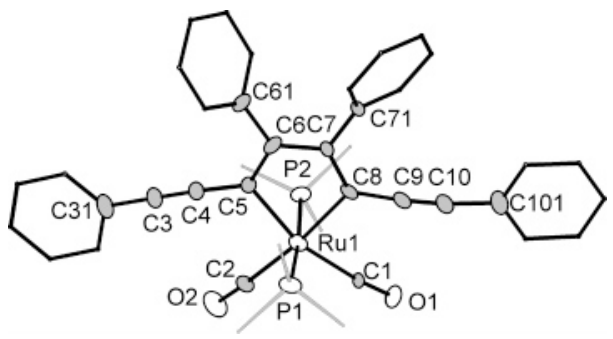

Figure 2. Molecular geometry of 9 in the crystal (50\% displacement ellipsoids, phosphine phenyl groups omitted, remaining phenyl groups simplified, hydrogen atoms omitted, one of two crystallographically independent molecules shown). Selected bond lengths $(\AA)$ and angles (deg): Ru1-P1 = 2.388(6), Ru1-P2 = 2.393(6), $\mathrm{Ru} 1-\mathrm{C} 1=2.00(2), \mathrm{Ru} 1-\mathrm{C} 2=1.99(2), \mathrm{Ru} 1-\mathrm{C} 5=2.19(2), \mathrm{Ru} 1-$ $\mathrm{C} 8=2.18(2), \mathrm{O} 1-\mathrm{C} 1=1.09(2), \mathrm{O} 2-\mathrm{C} 2=1.10(2), \mathrm{C} 3-\mathrm{C} 4=$ $1.19(3), \mathrm{C} 3-\mathrm{C} 31=1.42(3), \mathrm{C} 4-\mathrm{C} 5=1.43(3), \mathrm{C} 5-\mathrm{C} 6=1.37-$ (3), $\mathrm{C} 6-\mathrm{C} 7=1.46(3), \mathrm{C} 7-\mathrm{C} 8=1.37(3), \mathrm{C} 8-\mathrm{C} 9=1.42(3), \mathrm{C} 9-$ $\mathrm{C} 10=1.14(3) ; \mathrm{P} 1-\mathrm{Ru} 1-\mathrm{P} 2=174.4(3), \mathrm{C} 1-\mathrm{Ru} 1-\mathrm{C} 2=99.5(12)$, $\mathrm{C} 1-\mathrm{Ru} 1-\mathrm{C} 8=87.3(11), \mathrm{C} 2-\mathrm{Ru} 1-\mathrm{C} 5=96.4(11), \mathrm{C} 5-\mathrm{Ru} 1-$ $\mathrm{C} 8=76.8(10), \mathrm{Ru} 1-\mathrm{C} 1-\mathrm{O} 1=173(3), \mathrm{Ru} 1-\mathrm{C} 2-\mathrm{O} 2=176(3)$, $\mathrm{C} 4-\mathrm{C} 3-\mathrm{C} 3=178(3), \mathrm{C} 3-\mathrm{C} 4-\mathrm{C} 5=172(3), \mathrm{Ru} 1-\mathrm{C} 5-\mathrm{C} 4=$ 116(2), Ru1-C5-C6 = 115(2), C4-C5-C6 = 129(2), C5-C6$\mathrm{C} 7=116(2), \mathrm{C} 5-\mathrm{C} 6-\mathrm{C} 61=118(2), \mathrm{C} 7-\mathrm{C} 6-\mathrm{C} 61=126(2)$, $\mathrm{C} 6-\mathrm{C} 7-\mathrm{C} 8=118(2), \mathrm{C} 6-\mathrm{C} 7-\mathrm{C} 71=122(2), \mathrm{C} 8-\mathrm{C} 7-\mathrm{C} 71=$ $120(2), \mathrm{Ru} 1-\mathrm{C} 8-\mathrm{C} 7=114(2), \mathrm{Ru} 1-\mathrm{C} 8-\mathrm{C} 9=123(2), \mathrm{C} 7-\mathrm{C} 8-$ $\mathrm{C} 9=123(2), \mathrm{C} 8-\mathrm{C} 9-\mathrm{C} 10=174(3), \mathrm{C} 9-\mathrm{C} 10-\mathrm{C} 101=174(3)$.

crystallographically and shown to be the ruthenacyclopentadiene ("ruthenole") complex $\left[\mathrm{Ru}\left(\kappa^{2}-\mathrm{CR}=\mathrm{CPhCPh}=\mathrm{CR}\right)(\mathrm{CO})_{2}\left(\mathrm{PPh}_{3}\right)_{2}\right]$ (9, $\mathrm{R}=\mathrm{C} \equiv \mathrm{CPh}$; Scheme 1). The results of this study are summarized in Figure 2, which depicts one of two crystallographically independent but similar molecules of the metallacycle in the asymmetric unit. The geometric parameters of the " $\mathrm{Ru}(\mathrm{CO})_{2}\left(\mathrm{PPh}_{3}\right)_{2}$ " fragment are unremarkable for this metalligand combination in a $C_{2 v}$ octahedral arrangement. Bond distances around the $\mathrm{RuC}_{4}$ ring establish that 9 is best described as a ruthenacyclopentadiene, with an essentially localized $\mathrm{Ru}-$ $\mathrm{C}_{\alpha}, \mathrm{C}_{\alpha}=\mathrm{C}_{\beta}$, and $\mathrm{C}_{\beta}-\mathrm{C}_{\beta^{\prime}}$ bonding pattern. A ruthenacycle with the same connectivity, the complex $\left[\mathrm{RuBr}\left(\kappa^{2}-\mathrm{C}_{4} \mathrm{Ph}_{4}\right)\left(\eta-\mathrm{C}_{5} \mathrm{H}_{5}\right)\right]$ (10), has been alternatively described, with some justification, as a ruthencyclopentatriene. ${ }^{13}$ The dichotomy arises from the number of valence electrons required by the ruthenium to attain an 18-electron configuration. Table 2 summarizes structural parameters for the mononuclear ruthenacyclopentadienes 9-14, ${ }^{13-16}$ including Singleton's ruthenacyclopentatriene 10. ${ }^{13}$ Although not strictly mononuclear, the complex $\left\{\mathrm{Ru}\left\{\kappa^{2}-\mathrm{C}_{4}\left(\mathrm{CO}_{2}-\right.\right.\right.$ $\left.\left.\mathrm{Et})_{4}\right\}(\mathrm{CO})_{3}\right\}_{2}(\mathbf{1 4})$ is included, since the metallacyclopentadiene is not intimately involved in bridging the two metals; rather, the dimer is held together by weak coordination of the ester substituents. ${ }^{16}$ This is in contrast to the large number of bi- and polynuclear ruthenacyclopentadiene compounds wherein the prevalent "flyover" arrangement of the metallacyclopentadiene ("metallaole") supports a metal-metal bond. ${ }^{17}$

Structural data for 9, contextualized by Table 2, clearly indicate that the ruthenacyclopentadiene description is apt, consistent with the 16 -valence-electron nature of the " $\mathrm{Ru}(\mathrm{CO})_{2^{-}}$ $\left(\mathrm{PPh}_{3}\right)_{2}$ " fragment. Most relevant to the structure of $\mathbf{9}$ is the complex $\left[\mathrm{Ru}\left(\kappa^{2}-\mathrm{CR}=\mathrm{CPhCPh}=\mathrm{CR}\right)(\mathrm{CO})_{3}\left(\mathrm{NMe}_{3}\right)\right](\mathbf{1 1}, \mathrm{R}=$

(13) Albers, M. O.; De Waal, D. J. A.; Liles, D. C.; Robinson, D. J.; Singleton, E.; Wiege, M. B. J. Chem. Soc., Chem. Commun. 1986, 16801682.

(14) Bruce, M. I.; Zaitseva, N. N.; Skelton, B. W.; White, A. H. Inorg. Chim. Acta 1996, 250, 129.

(15) Burns, R. M.; Hubbard, J. L. J. Am. Chem. Soc. 1994, 116, 9514.

(16) Lindner, E.; Jansen, R.-M.; Mayer, H. A.; Hiller, W.; Fawzi, R. Organometallics 1989, 8, 2355.
Table 2. Structural Data (̊̊) for Ruthenacyclopentadienes and -trienes ${ }^{10,12-15}$

\begin{tabular}{|c|c|c|c|c|}
\hline complex & $a, \AA$ & $b, \AA$ & $c, \AA$ & $r^{a}$ \\
\hline 9 & $\begin{array}{l}2.178 \\
2.187\end{array}$ & $\begin{array}{l}1.367 \\
1.371\end{array}$ & 1.459 & 1.066 \\
\hline 11 & $\begin{array}{l}2.121 \\
2.10\end{array}$ & $\begin{array}{l}1.36 \\
1.38\end{array}$ & 1.46 & 1.066 \\
\hline 12 benzo & $\begin{array}{l}2.129 \\
2.093\end{array}$ & $\begin{array}{l}1.351 \\
1.422\end{array}$ & 1.437 & 1.036 \\
\hline 13 benzo & $\begin{array}{l}2.114 \\
2.088\end{array}$ & $\begin{array}{l}1.359 \\
1.400\end{array}$ & 1.472 & 1.067 \\
\hline 14 & $\begin{array}{l}2.109 \\
2.118\end{array}$ & $\begin{array}{l}1.347 \\
1.352\end{array}$ & 1.471 & 1.090 \\
\hline 10 & 1.942 & 1.403 & 1.377 & 1.019 \\
\hline
\end{tabular}

${ }^{a} r=2 c /\left(b+b^{\prime}\right)$ provides a singular indication of the degree of multiple bond localization.

$\mathrm{C} \equiv \mathrm{CPh}),{ }^{14}$ which has been obtained from the reaction of $\left[\mathrm{Ru}_{3}-\right.$ $\left.(\mathrm{NCMe})_{2}(\mathrm{CO})_{10}\right]$ with diphenylbutadiyne, the amine ligand arising from reduction of $\mathrm{Me}_{3} \mathrm{NO}$ required for the in situ synthesis of $\left[\mathrm{Ru}_{3}(\mathrm{NCMe})_{2}(\mathrm{CO})_{10}\right]$ from $\left[\mathrm{Ru}_{3}(\mathrm{CO})_{12}\right]$. The complex 11 was only obtained in $1.5 \%$ yield $(3 \mathrm{mg})$, precluding conjecture as to its mechanistic significance, with the major products being tri- and tetrametallic diyne complexes, in addition to a bimetallic ruthenacyclopentadiene and a diruthenatropolone. Each of these feature alkyne coupling with regiochemistries distinct from that required for the formation of either $\mathbf{9}$ or $\mathbf{1 1 .}$

(17) (a) Inagaki, A.; Takao, T.; Moriya, M.; Suzuki, H. Organometallics 2003, 22, 2196. (b) Inagaki, A.; Musaev, D. G.; Toshifumi, T.; Suzuki, H. Morokuma, K. Organometallics 2003, 22, 1718. (c) Bruce, M. I.; Pyke, S. M.; Zaitseva, N. N.; Skelton, B. W.; White, A. H. Helv. Chim. Acta 2001, 84, 3197. (d) Suzuki, H.; Inagaki, A.; Matsubara, K.; Takemori, T. Pure Appl. Chem. 2001, 73, 315. (e) Matsuzaka, H.; Ichikawa, K.; Ishioka, T.; Sato, H.; Okubo, T.; Ishii, T.; Yamashita, M.; Kondo, M.; Kitagawa, S. J. Organomet. Chem. 2000, 596, 121. (f) Inagaki, A.; Takenori, T.; Tanaka, M.; Suzuki, H. Angew. Chem., Int. Ed. 2000, 39, 404. (g) Zdanovich, V. I.; Lagunovoa, V. Yu.; Dolgushin, F. M.; Yanovsky, A. I.; Ezernitskaya, M. G.; Petrovskii, P. V.; Koridze, A. A. Russ. Chem. Bull. 1998, 47, 1789. (h) Koridze, A. A.; Zdanovich, V. I.; Lagunova, V. Yu.; Ezernitskaya, M. G.; Petrovskii, P. V.; Dolgushin, F. M.; Yanovsky, A. I. Russ. Chem. Bull. 1998, 47, 988. (i) Bruce, M. I.; Zaitseva, N. N.; Skelton, B. W.; White, A. H. Russ. Chem. Bull. 1998, 47, 983. (j) Bruce, M. I.; Hinchliffe, J. R.; Humphrey, P. A.; Surynt, R. J.; Skelton, B. W.; White, A. H. J. Organomet. Chem. 1998, 552, 109. (k) Bruce, M. I.; Zaitseva, N. N.; Skelton, B. W.; White, A. H. J. Organomet. Chem. 1997, 536/537, 93. (1) Tunik, S. P.; Grachova, E. V.; Denisov, V. R.; Starova, G. L.; Nikol'skii, A. B.; Dolgushin, F. M.; Yanovsky, A. I.; Struchkov, Yu. T. J. Organomet. Chem. 1997, 536/537, 339. (m) Blake, A. J.; Haggitt, J. L.; Johnson, B. F. G.; Parsons, S. J. Chem. Soc., Dalton Trans. 1997, 991. (n) Blenkiron, P.; Enright, G. D.; Carty, A. J. Chem. Commun. 1997, 483. (o) Koridze, A. A.; Zdanovich, V. I.; Andrievskaya, N. V.; Siromakhova, Yu.; Petrovskii, P. V.; Ezernitskaya, M. G.; Dolgushin, F. M.; Yanovskii, A. I.; Struchkov, Yu. T. Izv. Akad. Nauk, Ser. Khim. 1996, 1261; (p) Nishio, M.; Matsuzaka, H.; Mizobe, Y.; Tanase, T.; Hidai, M. Organometallics 1994, 13, 4214. (q) Suzuki, H.; Omori, H.; Lee, D.-H.; Yoshida, Y.; Fukushima, M.; Tanaka, M.; Moro-oka, Y. Organometallics 1994, 13, 1129. (r) Koridze, A. A.; Yanovsky, A. I.; Struchkov, Yu. T. J. Organomet. Chem. 1992, 441, 277. (s) Boroni, E.; Costa, M.; Predieri, G.; Sappa, E.; Tiripicchio, A. J. Chem. Soc., Dalton Trans. 1992, 2585. (s) Bruce, M. I.; Humphrey, P. A.; Miyamae, H.; Skelton, B. W.; White, A. H. J. Organomet. Chem. 1992, 429, 187. (t) Osella, D.; Gobetto, R.; Milone, L.; Zanello, P.; Mangani, S. Organometallics 1990, 9, 2167. (u) Campion, B. K.; Heyn, R. H.; Tilley, T. D. Organometallics 1990, 9, 1106. (v) Omori, H.; Suzuki, H.; Morooka, Y. Organometallics 1989, 8, 1576. (w) Han, S. H.; Geoffroy, G. L.; Rheingold, A. L. Organometallics 1987, 6, 2380. (x) Busetti, V.; Granozzi G.; Aime, S.; Gobetto, R.; Osella, D. Organometallics 1984, 3, 1510. (y) Bruce, M. I.; Matisons, J. G.; Skelton, B. W.; White, A. H. J. Organomet. Chem. 1983, 251, 249. (z) Noda, I.; Yasuda, H.; Nakamura, A. J. Organomet. Chem. 1983, 250, 447; (aa) Aime, S.; Deeming, A. J. J. Chem. Soc., Dalton Trans. 1981, 828. (ab) Low, P. J.; Udachin, K. A.; Enright, G. D.; Carty, A. J. J. Organomet. Chem. 1999, 578, 103. 
The regioselectivity observed in the exclusive formation of the $\alpha, \alpha^{\prime}$-bis(alkynyl)ruthenacyclopentadiene geometry of 9 is noteworthy; since phenyl substituents exert a greater steric influence than do alkynyls, it might be presumed that the regioselectivity is electronic in origin. Thus, while the location of the phenyl groups $\beta$ to the ruthenium and remote from the bulky phosphines in the final product may be the least sterically congested, this would involve greater steric pressures en route to the transition state for alkyne coupling (Scheme 1). The regiochemistry of diyne coupling is of interest in that the $\alpha, \alpha^{\prime}$ (i.e., 2,5) geometry may result in interesting electronic, nonlinear optical, and luminescent properties, as demonstrated by Marder for the luminescent rhodacyclopentadiene complex mer-[Rh$\left.\left(\mathrm{C} \equiv \mathrm{CSiMe}_{3}\right)\left(\mathrm{PMe}_{3}\right)_{3}\{\mathrm{C}(\mathrm{C} \equiv \mathrm{CR}) \mathrm{CRCRC}(\mathrm{C} \equiv \mathrm{CR})\}\right] \quad(\mathbf{1 5}, \mathrm{R}=$ $\left.\mathrm{C}_{6} \mathrm{H}_{4} \mathrm{Me}-4\right) .{ }^{18}$ The complex $\mathbf{1 5}$ may be considered isoelectronic

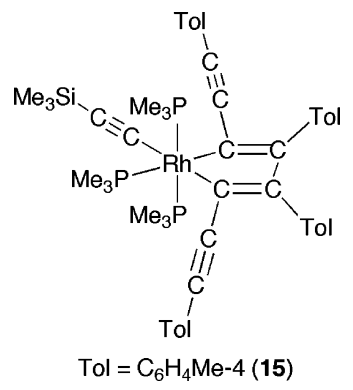

with 9, although the coligand sets are quite disparate, the former being devoid of effective $\pi$ acidic ligands while the latter has strong $\pi$ acids trans to the metallacycle. Unfortunately, Marder's complex $\mathbf{1 5}$ is a unique example (now augmented by 9) where, within detectable limits, the desired $\alpha, \alpha^{\prime}$ isomer is exclusively formed, in high yield. Thus, while other mononuclear bis(alkynyl)metallacyclopentadienes have been obtained via diyne coupling (16-19), ${ }^{19}$ the desirable $\alpha, \alpha^{\prime}$ isomer is either not formed, or is the minor component.
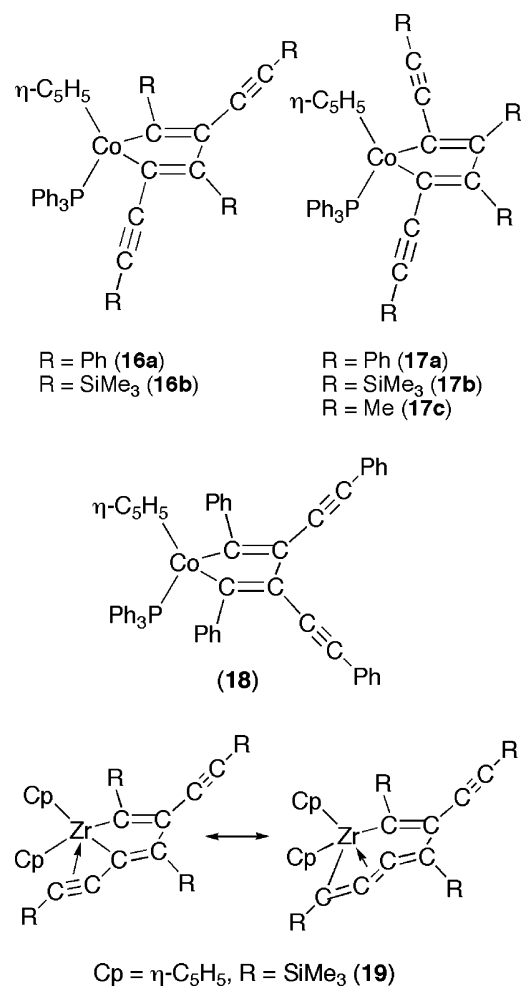

We have not spectroscopically detected alternative regioisomers. Our attempts to extend this reaction to bis(trimethylsilyl)- butadiyne have so far been unsuccessful. Heating $\mathbf{1}$ with excess $\mathrm{Me}_{3} \mathrm{SiC} \equiv \mathrm{CC} \equiv \mathrm{CSiMe}_{3}$ in toluene under reflux provides an inseparable mixture of numerous phosphine complexes $\left({ }^{31} \mathrm{P}\right.$ $\left\{{ }^{1} \mathrm{H}\right\}$ NMR: inter alia $\delta_{\mathrm{P}} 33.6,35.7,49.1,49.4,50.6,51.3,51.9$, $54.1,56.6)$, the predominant species being $\left[\mathrm{Ru}(\mathrm{CO})_{3}\left(\mathrm{PPh}_{3}\right)_{2}\right]$ $\left(2 ; \delta_{\mathrm{P}} 57.1\right)$. The reaction of 1 with $\mathrm{Me}_{3} \mathrm{SiC} \equiv \mathrm{CC} \equiv \mathrm{CSiMe}_{3}$ under ambient conditions leads to a 5:1 equilibrium mixture of 1 and what we presume to be the simple but very labile diyne complex $\left[\mathrm{Ru}\left(\eta-\mathrm{Me}_{3} \mathrm{SiC} \equiv \mathrm{CC} \equiv \mathrm{CSiMe}_{3}\right)(\mathrm{CO})_{2}\left(\mathrm{PPh}_{3}\right)_{2}\right]$ (4c) on the basis of a ${ }^{31} \mathrm{P}\left\{{ }^{1} \mathrm{H}\right\}$ resonance at $\delta_{\mathrm{P}} 45.5$, in a region comparable to that for $\mathbf{4 b}\left(\delta_{\mathrm{P}} 43.7\right)$. Attempts to isolate $\mathbf{4 c}$, however, only led to recovery of the sparingly soluble $\mathbf{1}$ from a presumed crystallization-perturbed equilibrium, indicating that the liberated phosphine competes effectively with the diyne. In a similar manner, the reaction of $\left[\mathrm{Ru}\left(\eta-\mathrm{C}_{2} \mathrm{H}_{4}\right)(\mathrm{CO})_{2}\left(\mathrm{PPh}_{3}\right)_{2}\right]$ $(\mathbf{2 0})^{4}$ with $\mathrm{Me}_{3} \mathrm{SiC} \equiv \mathrm{CC} \equiv \mathrm{CSiMe}_{3}$ proceeds to an approximate

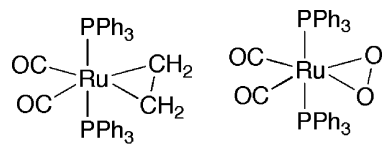

(20)

(21)

2:1 equilibrium mixture of $\mathbf{2 0}\left(\delta_{\mathrm{P}} 58.0\right)$ and $\mathbf{4 c}$ when carried out in a sealed vessel. However, in contrast to the reaction of 1 and $\mathrm{Me}_{3} \mathrm{SiC} \equiv \mathrm{CC} \equiv \mathrm{CSiMe}_{3}$, the volatility of ethylene allows the equilibrium to be drawn to the formation of $\mathbf{4 c}$ by either a continuous nitrogen purge of the system or, alternatively (and more effectively), by removing the ethylene by periodic evacuation of the reaction vessel. The increased lability of $\mathrm{Me}_{3}-$ $\mathrm{SiC} \equiv \mathrm{CC} \equiv \mathrm{CSiMe}_{3}$ in $\mathbf{4} \mathbf{c}$ relative to that of $\mathrm{PhC} \equiv \mathrm{CC} \equiv \mathrm{CPh}$ in $\mathbf{4 b}$ has compromised the acquisition of satisfactory elemental microanalytical data, with samples being invariably contaminated with $\left[\mathrm{Ru}\left(\eta-\mathrm{O}_{2}\right)(\mathrm{CO})_{2}\left(\mathrm{PPh}_{3}\right)_{2}\right]\left(\mathbf{2 1} ;{ }^{4} \delta_{\mathrm{P}} 34.9\right),{ }^{20}$ the formation of which is essentially irreversible. Ruthenacyclopentadienes have come to be recognized as mechanistically significant species in a range of alkyne transformations mediated by lowvalent ruthenium complexes. This has included the synthesis of pyridines from nitriles and $\alpha, \omega$-diynes,${ }^{21}$ the cycloisomerization of diynols to 2-vinyl-1-acylcycloalkenes, ${ }^{22}$ and the catalytic linear coupling of alkynes with alkenes. ${ }^{23}$ Ruthenacyclopentadienes might also appear as attractive mechanistic intermediates in the formation of cyclopentadienone complexes, for which there are many ruthenium examples. ${ }^{3,5,6,24}$ However, the stability of 9 (recovered unchanged from refluxing xylene) would appear to add to the evidence against such routes. Furthermore, we note that $\mathbf{9}$ fails to react with either carbon monoxide or ethyne ( $2 \mathrm{~atm}, d_{6}$-benzene, $80{ }^{\circ} \mathrm{C}$ ). These reagents might be expected to intercept any coordinatively unsaturated ruthenacyclohexadienone tautomer if formed, given that [Os$\left.(\mathrm{SCCH}=\mathrm{CHCH}=\mathrm{CH})(\mathrm{CO})\left(\mathrm{PPh}_{3}\right)_{2}\right]$ reacts rapidly with $\mathrm{CO} .{ }^{25}$

(18) Rourke, J. P.; Batsanov, A. S.; Howard, J. A. K.; Marder, T. B. Chem. Commun. 2001, 2626.

(19) (a) Shimura, T.; Ohkubo, A.; Aramaki, K.; Uekusa, H.; Fujita, T.; Ohba, S.; Nishihara, H. Inorg. Chim. Acta 1995, 230, 215. (b) Fujita, T.; Uekusa, H.; Ohkubo, A.; Shimura, T.; Aramaki, K.; Nishihara, H.; Ohba, S. Acta Crystallogr. 1995, C51, 2265. (c) Hsu, D. P.; Davis, W. M.; Buchwald, S. L. J. Am. Chem. Soc. 1993, 115, 10394. (d) Burlakov, V. V.; Ohff, A.; Lefeber, C.; Tillack, A.; Baumann, W.; Kempe, R.; Rosenthal, U. Chem. Ber. 1995, 128, 967. (e) Rosenthal, U.; Pellny, P.-M; Kirchbauer, F. G.; Burlakov, V. V. Acc. Chem. Res. 2000, 33, 119.

(20) The complex was also crystallographically characterized and refined to a more precise model than that previously reported $(R=0.066)$ in: Hiraki, K.; Kira, S.; Kawano, H. Bull. Chem. Soc. Jpn. 1997, 70, 1583.

(21) Varela, J. A.; Castedo, L.; Saa, C. J. Org. Chem. 2003, 68, 8595.

(22) Trost, B. M.; Rudd, M. T. J. Am. Chem. Soc. 2003, 125, 11516.

(23) Yi, C. S.; Liu, N. Synlett 1999, 281. 
Scheme 2. Systematic Preparation of cct-22 $\left(\mathbf{L}=\mathbf{P P h}_{3}\right)$

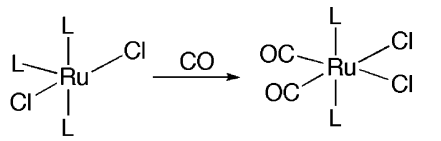<smiles>O=C(c1ccccc1)C(Cl)(I)[V](=O)(I)I</smiles>

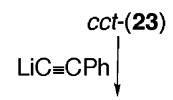<smiles>[O-][Ge](I)(I)C#Cc1ccccc1</smiles>

(26)<smiles>O=[W]([O-])(O)(I)(C#Cc1ccccc1)C#Cc1ccccc1</smiles>

cct-(22)

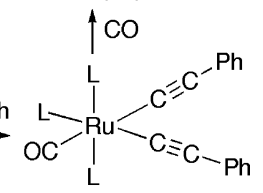

(25a)
Although they were eventually obtained, crystallographic grade crystals of 9 were not immediately forthcoming, a situation that led us to explore possible formulations for $\mathbf{9}$ via the less fashionable technique of unequivocal independent synthesis, summarized in Scheme 2. Our initial suspicions focused on the previously unknown complex $\left[\mathrm{Ru}(\mathrm{C} \equiv \mathrm{CPh})_{2}(\mathrm{CO})_{2}\left(\mathrm{PPh}_{3}\right)_{2}\right](\mathbf{2 2})$,

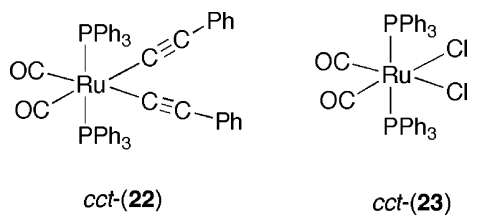

perhaps arising from $\mathrm{C}-\mathrm{C}$ bond cleavage by analogy with $\mathbf{4 d}$ or $\mathbf{4 e}$, which readily oxidatively add one $\mathrm{C}-\mathrm{C}$ bond. ${ }^{1}$ The complexes $\left[\mathrm{Ru}(\mathrm{C} \equiv \mathrm{CPh})_{2}(\mathrm{CO})_{2}\left(\mathrm{PR}_{3}\right)_{2}\right]\left(\mathrm{R}=\mathrm{Et}\right.$, $\left.{ }^{\mathrm{i}} \mathrm{Pr}\right)$ arise from the reaction of $\left[\mathrm{RuCl}_{2}(\mathrm{CO})_{2}\left(\mathrm{PEt}_{3}\right)_{2}\right]$ with $\mathrm{LiC} \equiv \mathrm{CPh}^{26}$ and carbonylation of $\left[\mathrm{Ru}(\mathrm{C} \equiv \mathrm{CPh})_{2}(\mathrm{CO})\left(\mathrm{P}^{i} \mathrm{Pr}_{3}\right)_{2}\right],{ }^{27}$ respectively, and it is noteworthy that they have distinct geometries; the $\mathrm{PEt}_{3}$ derivative assumes the all-trans geometry, in contrast to cis, cis,trans- $\left[\mathrm{Ru}(\mathrm{C} \equiv \mathrm{CPh})_{2}(\mathrm{CO})_{2}\left(\mathrm{P}^{\mathrm{i}} \mathrm{Pr}_{3}\right)_{2}\right]$. Applying the former strategy ${ }^{26}$ to the synthesis of the $\mathrm{PPh}_{3}$ derivative 22, we find that it is in fact the cct-22 isomer that is obtained upon treating $c c t-\left[\mathrm{RuCl}_{2}(\mathrm{CO})_{2}\left(\mathrm{PPh}_{3}\right)_{2}\right]\left(\mathbf{2 3} ;{ }^{31} \mathrm{P}\left\{{ }^{1} \mathrm{H}\right\} \mathrm{NMR} \delta\right.$ 17.7, IR 2056, $1998 \mathrm{~cm}^{-1}$ ) with freshly prepared lithium phenylacetylide (from

(24) (a) Smith, T. P.; Kwan, K. S.; Taube, H.; Bino, A.; Cohen, S. Inorg. Chem. 1984, 23, 1943. (b) Koridze, A. A.; Zdanovich, V. I.; Lagunova, V. Y.; Petukhova, I. I.; Dolgushin, F. M.; Starikova, Z. A.; Ezernitskaya, M. G.; Petrovskii, P. V. Izv. Akad. Nauk SSSR, Ser. Khim. 2002, 807. (c) Yamazaki, Y.; Goto, M.; Kageyama, Y.; Tomohiro, T.; Okuno, H. Z. Naturforsch. 1996, 51b, 301. (d) Schneider, B.; Goldberg, I.; Reshef, D.; Stein, Z.; Shvo, Y. J. Organomet. Chem. 1999, 588, 92. (e) Shvo, Y.; Czarkie, D.; Rahamim, Y.; Chodosh, D. F. J. Am. Chem. Soc. 1986, 108, 7400. (f) Akabori, S.; Kumagai, T.; Shirahige, T.; Sato, S.; Kawazoe, K.; Tamura, C.; Sato, M. Organometallics 1987, 6, 2105. (g) Casey, C. P.; Singer, S. W.; Powell, D. R.; Hayashi, R. K. Kavana, M. J. Am. Chem. Soc. 2001, 123, 1090. (h) Hill, A. F.; Schultz, M.; Willis, A. C. Organometallics 2005, 24, 2027. (i) Meijer, R. H.; Ligthart, G. B. W. L.; Meuldijk, J.; Vekemans, J. A. J. M.; Hulshof. L. A.; Mills, A. M.; Kooijman, H.; Spek, A. L. Tetrahedron 2004, 60, 1065.

(25) Elliott, G. P.; Roper, W. R.; Waters, J. M. J. Chem. Soc., Chem. Commun. 1982, 811.

(26) Sun, Y.; Taylor, N. J.; Carty, A. J. Organometallics 1992, 11, 4293. (b) Sun, Y.; Taylor, N. J.; Carty, A. J. J. Organomet. Chem. 1992, 423, C43.

(27) (a) Werner, H.; Esteruelas, M. A.; Otto, H. Organometallics 1986, 5, 2295. (b) Werner, H.; Meyer, U.; Esteruelas, M. A.; Sola, E.; Oro, L. A. J. Organomet. Chem. 1989, 366, 187. (c) Esteruelas, M. A.; Lahoz, F. J.; Lopez, A. M.; Oñate, E.; Oro, L. A. Organometallics 1994, 13, 1669.

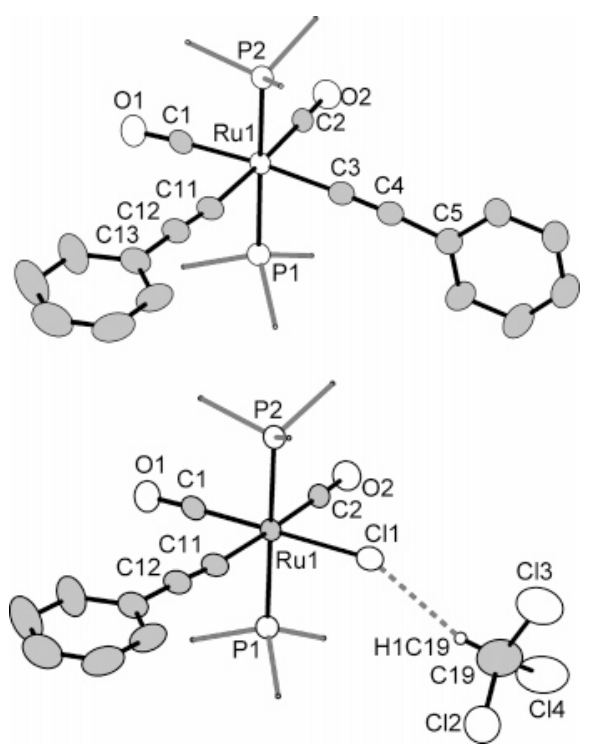

Figure 3. (a, top) Molecular geometry of 22 in a crystal of $\mathbf{2 2}_{0.896^{-}}$ $\left(\mathbf{2 4 a} \cdot \mathrm{CHCl}_{3}\right)_{0.104}(50 \%$ displacement ellipsoids, phosphine phenyl groups and hydrogen atoms omitted). Selected bond lengths (A) and angles (deg): Ru1-P1 = 2.392(1), Ru1-P2 = 2.380(1), Ru1$\mathrm{C} 1=1.921(5), \mathrm{Ru} 1-\mathrm{C} 2=1.916(5), \mathrm{Ru} 1-\mathrm{C} 3=2.068(4), \mathrm{Ru} 1-$ $\mathrm{C} 11=2.088(5), \mathrm{O} 1-\mathrm{C} 1=1.133(5), \mathrm{O} 2-\mathrm{C} 2=1.137(5), \mathrm{C} 3-$ $\mathrm{C} 4=1.194(6), \mathrm{C} 4-\mathrm{C} 5=1.448(5), \mathrm{C} 11-\mathrm{C} 12=1.177(7) ; \mathrm{P} 1-$ $\mathrm{Ru} 1-\mathrm{P} 2=175.3(1), \mathrm{C} 1-\mathrm{Ru} 1-\mathrm{C} 2=95.7(2), \mathrm{C} 1-\mathrm{Ru} 1-\mathrm{C} 11=$ 82.1(2), C2-Ru1-C3 = 89.2(2), C3-Ru1-C11 = 93.1(2), Ru1$\mathrm{C} 1-\mathrm{O} 1=178.0(4), \mathrm{Ru} 1-\mathrm{C} 2-\mathrm{O} 2=178.4(4), \mathrm{Ru} 1-\mathrm{C} 3-\mathrm{C} 4=$ 171.8(5), C3-C4-C5 = 170.6(6), Ru1-C11-C12 = 171.7(5), $\mathrm{C} 11-\mathrm{C} 12-\mathrm{C} 13=177.9(6)$. (b, bottom) Molecular geometry of $\mathbf{2 4 a}$ in a crystal of $\mathbf{2 2}_{0.896}\left(\mathbf{2 4 a} \cdot \mathrm{CHCl}_{3}\right)_{0.104}(50 \%$ displacement ellipsoids, phosphine phenyl groups and hydrogen atoms omitted). Selected bond lengths $(\AA)$ and angles $(\mathrm{deg})$ : $\mathrm{Ru} 1-\mathrm{Cl1}=2.572$ (12), $\mathrm{Cl1} \cdots \mathrm{H} 1 \mathrm{C} 19=2.66(1) ; \mathrm{Cl1} \cdots \mathrm{H} 1 \mathrm{C} 19-\mathrm{C} 19=156(3)^{\circ}$. Other metric parameters are as for 22.

${ }^{n} \mathrm{BuLi}$ and $\left.\mathrm{HC} \equiv \mathrm{CPh}\right)$. This reaction proceeds via the monosubstitution product $\left[\mathrm{RuCl}(\mathrm{C} \equiv \mathrm{CPh})(\mathrm{CO})_{2}\left(\mathrm{PPh}_{3}\right)_{2}\right]$ (24a) (ob-

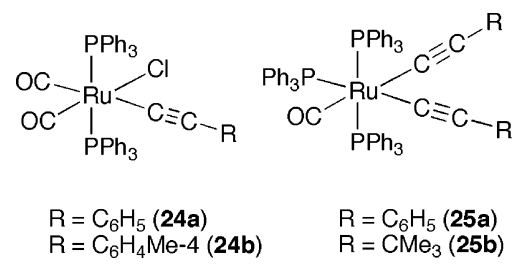

served by ${ }^{31} \mathrm{P}\left\{{ }^{1} \mathrm{H}\right\}$ NMR spectroscopy, $\delta 22.5$, but not isolated) to the desired compound $c c t-\mathbf{2 2}$. The intermediate complex $\mathbf{2 4 a}$ is analogous to $\left[\mathrm{Ru}\left(\mathrm{C} \equiv \mathrm{CC}_{6} \mathrm{H}_{4} \mathrm{Me}-4\right) \mathrm{Cl}(\mathrm{CO})_{2}\left(\mathrm{PPh}_{3}\right)_{2}\right]\left(\mathbf{2 4 b} ; \delta_{\mathrm{P}}\right.$ 23.1), which was has been previously obtained via an alternative route that ensures exclusive formation of the monosubstituted derivative. $^{28}$ Although the stereochemistry of $\mathbf{2 2}$ follows from spectroscopic data (two $v(\mathrm{CO})$ IR absorptions, one ${ }^{31} \mathrm{P}$ resonance, and virtual triplet $\mathrm{C}^{1,2,3,5,6}\left(\mathrm{PC}_{6} \mathrm{H}_{5}\right){ }^{13} \mathrm{C}$ resonances $)$, the complex was also structurally characterized. The molecular geometry of $\mathbf{2 2}$ is summarized in Figure 3. Notably, detailed analysis of the diffraction data indicated that the small twinned needle chosen for study was a solid solution of 22 and the intermediate $\mathbf{2 4 a}$. In retrospect, it should be noted that the model

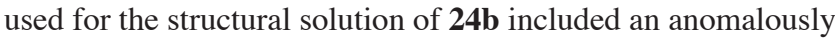
short $\mathrm{C} \equiv \mathrm{C}$ bond length that may well have arisen from a similar superposition of chloride and alkynyl groups. In the present

(28) Bedford, R. B.; Hill, A. F.; Thompsett, A. R.; White, A. J. P.; Williams, D. J. Chem. Commun. 1996, 1059. 
study, a model based on a $(\mathbf{2 2})_{0.894}\left(\mathbf{2 4 a} \cdot \mathrm{CHCl}_{3}\right)_{0.106}$ stoichiometry was refined satisfactorily, and information in Figure $3 \mathrm{a}$ is based on the major contributor 22, while Figure $3 b$ depicts the minor component $\mathbf{2 4 a} \cdot \mathrm{CHCl}_{3}$. Although the structural study confirms the expected identity and connectivity, the nonstandard nature of the solution makes it inappropriate to discuss geometrical features in detail, other than to note that the stereochemistry agrees with that predicted on the basis of spectroscopic data.

Our initial attempt to prepare $\mathbf{2 2}$ involved the synthesis of the precursor cct-23 via carbonylation (1 atm, $\left.\mathrm{CH}_{2} \mathrm{Cl}_{2}\right)$ of $\left[\mathrm{RuCl}_{2}\left(\mathrm{PPh}_{3}\right)_{3}\right]$, which provided a mixture of ttt-23 (IR 2000 $\mathrm{cm}^{-1}$ ) and $c c t-23$ isomers (IR 2063, $1999 \mathrm{~cm}^{-1}$ ). Heating this mixture under reflux followed by crystallization from dichloromethane and ethanol appeared to give the pure $c c t-\mathbf{2 3}$ isomer, as described previously. ${ }^{29,30}$ However, during attempts to obtain crystals of $\mathbf{2 2}$ from an apparently spectroscopically pure solution of that compound, a few crystals of a second compound were obtained and structurally characterized as the sparingly soluble complex cis,mer- $\left[\mathrm{Ru}(\mathrm{C} \equiv \mathrm{CPh})_{2}(\mathrm{CO})\left(\mathrm{PPh}_{3}\right)_{3}\right]$ (25a). This compound has been briefly mentioned in a previous report, ${ }^{31}$ in which it was obtained via the reaction of $\left[\mathrm{Ru}\left(\mathrm{C} \equiv \mathrm{CCMe}_{3}\right)_{2}(\mathrm{CO})\right.$ $\left.\left(\mathrm{PPh}_{3}\right)_{3}\right](\mathbf{2 5 b})$ with excess phenylacetylene and characterized on the basis of melting point, infrared $(\nu(\mathrm{C} \equiv \mathrm{C}) 2075 ; \nu(\mathrm{CO})$ $1965 \mathrm{~cm}^{-1}$ ) and elemental data (for the $1.5 \mathrm{C}_{6} \mathrm{H}_{6}$ solvate). ${ }^{35}$ Given that our structural characterization arose inadvertently, more complete characterization thus seemed desirable (see Experimental Section). The complex was therefore obtained on a preparative scale via a two-step sequence: the complex [RuH$\left.(\mathrm{C} \equiv \mathrm{CPh})(\mathrm{CO})\left(\mathrm{PPh}_{3}\right)_{3}\right](\mathbf{2 6})$ is available via either the reaction

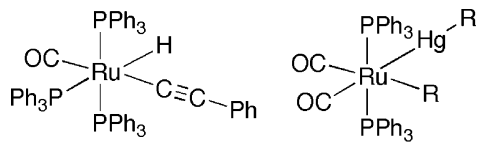

(26)

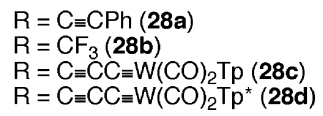

of $\left[\mathrm{RuH}\left(\kappa^{2}-\mathrm{C}_{6} \mathrm{H}_{4} \mathrm{PPh}_{2}\right)(\mathrm{CO})\left(\mathrm{PPh}_{3}\right)_{2}\right]^{32}$ with $\mathrm{HC} \equiv \mathrm{CPh}^{33}$ or of $\left[\mathrm{RuHCl}(\mathrm{CO})\left(\mathrm{PPh}_{3}\right)_{3}\right]$ with $\mathrm{LiC} \equiv \mathrm{CPh} .{ }^{31}$ The former route avoids contamination with $\left[\mathrm{Ru}(\mathrm{CH}=\mathrm{CHPh}) \mathrm{Cl}(\mathrm{CO})\left(\mathrm{PPh}_{3}\right)_{2}\right]^{34}$ but is less convenient for large-scale preparations, due to the requisite involvement of organomercurials in the synthesis of $\left[\mathrm{RuH}\left(\kappa^{2}-\right.\right.$ $\left.\left.\mathrm{C}_{6} \mathrm{H}_{4} \mathrm{PPh}_{2}\right)(\mathrm{CO})\left(\mathrm{PPh}_{3}\right)_{2}\right]$. The sample of $\mathbf{2 6}$ we obtained via the latter route has spectroscopic data $\left(\delta_{\mathrm{H}}-7.68\left({ }^{2} J_{\mathrm{PH}}=86,25\right.\right.$ $\mathrm{Hz})$; IR (Nujol) $\left.2088\left(v_{\mathrm{C} \equiv \mathrm{C}}\right), 2000\left(v_{\mathrm{RuH}}\right), 1938\left(v_{\mathrm{CO}}\right)\right)$ somewhat different from those reported $\left(\delta_{\mathrm{H}}=-8.13\left({ }^{2} J_{\mathrm{PH}}=85,25 \mathrm{~Hz}\right)\right.$; $\left.\operatorname{IR}(\mathrm{KBr}) 2012\left(v_{\mathrm{C} \equiv \mathrm{C}}\right), 1993\left(\nu_{\mathrm{RuH}}\right), 1923\left(v_{\mathrm{CO}}\right)\right) .28,32$ However, with additional ${ }^{31} \mathrm{P}\left\{{ }^{1} \mathrm{H}\right\}$ NMR data $\left(\delta_{\mathrm{P}} 45.03(\mathrm{~d}), 23.95(\mathrm{t}),{ }^{2} J_{\mathrm{PP}}\right.$ $=16 \mathrm{~Hz}$ ) we are confident of the authenticity of our product. Treating 26 with excess $\mathrm{HC} \equiv \mathrm{CPh}$ in toluene provides $\mathbf{2 5 a}$ over $48 \mathrm{~h}$, which in turn is cleanly carbonylated $\left(26{ }^{\circ} \mathrm{C}, \mathrm{CH}_{2} \mathrm{Cl}_{2}, 1\right.$ atm) to provide $c c t-22$ (Scheme 2).

(29) James, B. R.; Markham, L. D.; Hui, B. C.; Rempel, G. L. J. Chem. Soc., Dalton Trans. 1973, 2247. 945.

(30) Stephenson, T. A.; Wilkinson, G. J. Inorg. Nucl. Chem. 1966, 28,

(31) Wakatsuki, Y.; Yamazaki, H.; Kumegawa, N.; Satoh, T.; Satoh, J. Y. J. Am. Chem. Soc. 1991, 113, 9604.

(32) Roper, W. R.; Wright, L. J. J. Organomet. Chem. 1982, 234 , C5. (33) Wright, L. J. Ph.D. Thesis, University of Auckland, 1980.

(34) Torres, M. R.; Vegas, A.; Santos, A.; Ros, J. J. Organomet. Chem. 1986, 309, 169.

(35) Elemental microanalytical data reported in ref 31 were erroneously calculated for $\mathrm{C}_{69} \mathrm{H}_{56} \mathrm{OP}_{3} \mathrm{Ru}$ rather than the correct formula $\mathrm{C}_{63} \mathrm{H}_{51} \mathrm{OP}_{3} \mathrm{Ru}$.

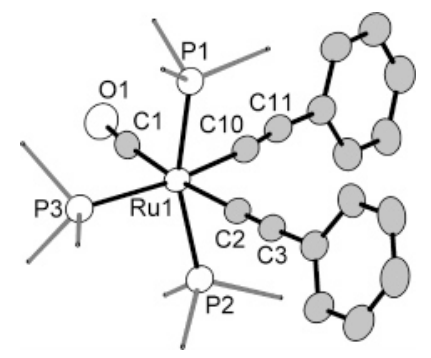

Figure 4. Molecular geometry of 25a in a crystal of $\mathbf{2 5 a} \cdot \mathrm{CH}_{2} \mathrm{Cl}_{2}$ (50\% displacement ellipsoids, phenyl groups simplified, hydrogen atoms omitted). Selected bond lengths ( $\AA$ ) and angles (deg): Ru1$\mathrm{P} 1=2.377(3), \mathrm{Ru} 1-\mathrm{P} 2=2.419(3), \mathrm{Ru} 1-\mathrm{P} 3=2.478(3), \mathrm{Ru} 1-$ $\mathrm{C} 1=1.910(10), \mathrm{Ru} 1-\mathrm{C} 2=2.058(9), \mathrm{Ru} 1-\mathrm{C} 10=2.034(9), \mathrm{O} 1-$ $\mathrm{C} 1=1.139(9), \mathrm{C} 2-\mathrm{C} 3=1.192(10), \mathrm{C} 3-\mathrm{C} 4=1.475(10), \mathrm{C} 10-$ $\mathrm{C} 11=1.186(10), \mathrm{C} 11-\mathrm{C} 12=1.459(10) ; \mathrm{P} 1-\mathrm{Ru} 1-\mathrm{P} 2=161.5(1)$, $\mathrm{P} 1-\mathrm{Ru} 1-\mathrm{P} 3=97.8(1), \mathrm{P} 1-\mathrm{Ru} 1-\mathrm{C} 1=91.1(3), \mathrm{P} 1-\mathrm{Ru} 1-\mathrm{C} 2=$ $85.5(2), \mathrm{P} 1-\mathrm{Ru} 1-\mathrm{C} 10=82.8(2), \mathrm{P} 2-\mathrm{Ru} 1-\mathrm{P} 3=97.6(1), \mathrm{P} 2-$ $\mathrm{Ru} 1-\mathrm{C} 1=99.9(3), \mathrm{P} 2-\mathrm{Ru} 1-\mathrm{C} 2=82.2(2), \mathrm{P} 2-\mathrm{Ru} 1-\mathrm{C} 10=$ 84.1(2), P3-Ru1-C1 = 86.9(3), P3-Ru1-C2 = 98.3(2), C1$\mathrm{Ru} 1-\mathrm{C} 10=81.4(4), \mathrm{C} 2-\mathrm{Ru} 1-\mathrm{C} 10=93.4(3), \mathrm{Ru} 1-\mathrm{C} 1-\mathrm{O} 1=$ 174.6(9), Ru1-C2-C3 = 178.6(8), C2-C3-C4 = 176.7(9), Ru1$\mathrm{C} 10-\mathrm{C} 11=169.7(8), \mathrm{C} 10-\mathrm{C} 11-\mathrm{C} 12=173.6(9)$.

The molecular geometry of $\mathbf{2 5 a}$ is summarized in Figure 4, which reveals a distorted-octahedral geometry about the sixcoordinate ruthenium center. The primary distortions may be attributed to the steric pressures associated with the meridional coordination of three bulky phosphine ligands. Somewhat surprisingly, there are very few structural data presently available for the mer- $\mathrm{M}\left(\mathrm{PPh}_{3}\right)_{3}$ geometry at a six-coordinate metal that do not include at least one hydride coligand (and attendant deformations). Indeed, these are limited to the rhenium salts $\left[\mathrm{ReF}(\mathrm{CO})(\mathrm{NO})\left(\mathrm{PPh}_{3}\right)_{3}\right] \mathrm{ClO}_{4}{ }^{36}$ and (17-electron) $\left[\mathrm{Re}\left(\mathrm{O}_{2} \mathrm{CMe}\right)\right.$ (CO) $\left.\left(\mathrm{PPh}_{3}\right)_{3}\right] \mathrm{PF}_{6}{ }^{37}$ Unit cell data are available for the complex $\mathbf{2 5} \mathbf{b} ;{ }^{10,38}$ however, geometric data have yet to appear, precluding useful comment. The $\mathrm{Ru}\left(\mathrm{PPh}_{3}\right)_{3}$ fragment in 25a is deformed from ideal octahedral geometry such that the angle between trans phosphorus donors is reduced to $161.5(1)^{\circ}$ with cis angles between these and P2 being 97.8(1) and 97.6(1) ${ }^{\circ}$. Similar angles $\left(161.9,94.7\right.$, and $\left.96.8^{\circ}\right)$ are observed for $\left[\mathrm{ReF}(\mathrm{CO})(\mathrm{NO})\left(\mathrm{PPh}_{3}\right)_{3}\right]$ $\mathrm{ClO}_{4}{ }^{36}$ The alkynyl ligands in 25a show statistically identical $\mathrm{C} \equiv \mathrm{C}$ bond lengths (1.187(13), 1.192(11) $\AA$ ) and comparable alkynyl $\mathrm{Ru}-\mathrm{C}$ bond lengths (2.034(9), 2.057(8) $\AA$ ), with these values falling within the range for six-coordinate ruthenium alkynyls. ${ }^{10}$ The two mutually trans phosphine ligands are arranged so as to allow one phenyl group from each to nestle between the two alkynyl ligands, their planes lying almost orthogonal to the bis(alkynyl) coordination plane.

The origin of the initially obtained crystals of $\mathbf{2 5} \mathbf{a}$ remains a mystery, but these could in principle arise from two possible complications. First, the carbonylation of $\left[\mathrm{RuCl}_{2}\left(\mathrm{PPh}_{3}\right)_{3}\right]$ provides a solvent-dependent mixture of $c c t-\mathbf{2 3}$ and $\mathbf{t t t}-\mathbf{2 3}$. $^{29,30}$ Heating or recrystallization is presumed to result in complete conversion to the $c c t-\mathbf{2 3}$ isomer. However, given the overlap of infrared bands for both isomers, there exists the possibility that residual amounts of the ttt-23 isomer remained and that subsequent reaction provided $t t t-\mathbf{2 2}$, the mutually trans carbonyl

(36) Cameron, T. S.; Grundy, K. R.; Robertson, K. N. Inorg. Chem. 1982 , $21,4149$.

(37) (a) Cameron, C. J.; Fanwick, P. E.; Leeaphon, M.; Waltron, R. A. Inorg. Chem. 1989, 18, 1101. N.B.: when one considers the curious void in the coordination sphere of this complex and its coordinative unsaturation (17 electrons), it is tempting to consider an alternative formulation as the 18-electron hydride complex $\left[\mathrm{ReH}\left(\mathrm{O}_{2} \mathrm{CMe}\right)(\mathrm{CO})\left(\mathrm{PPh}_{3}\right)_{3}\right]^{+}$.

(38) Wakatsuki, Y.; Satoh, M.; Yamazaki, H. Chem. Lett. 1989, 1585. 
ligands of which might be expected to be more labile. Since the species $t t t-23\left(v_{\mathrm{CO}} 2005 \mathrm{~cm}^{-1}\right)$ and $c c t-23\left(v_{\mathrm{CO}} 2064,2001\right.$ $\mathrm{cm}^{-1}$ ) have a coincident infrared absorption, the presence of the former could well have been masked by the latter. Alternatively, under different conditions, monocarbonylation of $\left[\mathrm{RuCl}_{2}\left(\mathrm{PPh}_{3}\right)_{3}\right]$ in dimethylacetamide (dma) has been reported to provide $\left[\mathrm{RuCl}_{2}(\mathrm{CO})(\mathrm{dma})\left(\mathrm{PPh}_{3}\right)_{2}\right]$, recrystallization of which from $\mathrm{CH}_{2} \mathrm{Cl}_{2}$ and $\mathrm{MeOH}$ provides the 16-electron species $\left[\mathrm{RuCl}_{2}(\mathrm{CO})\left(\mathrm{PPh}_{3}\right)_{2}\right] .{ }^{29,30}$ Were this species to be present, then reaction with $\mathrm{LiC} \equiv \mathrm{CPh}$ and adventitious phosphine would be expected to provide 25a. The complex $\left[\mathrm{Ru}(\mathrm{C} \equiv \mathrm{CPh})_{2}(\mathrm{CO})\left(\mathrm{P}^{\mathrm{i}}-\right.\right.$ $\left.\left.\mathrm{Pr}_{3}\right)_{2}\right]$ is isolable as a stable 16 -electron species ${ }^{27}$ due to the steric bulk of the $\mathrm{PiPr}_{3}$ ligands, while three of the more sterically modest $\mathrm{PPh}_{3}$ ligands can be accommodated in 25a.

An alternative approach to the synthesis of $\mathbf{2 2}$ was investigated via the oxidative addition of bis(phenylethynyl)mercury (27) ${ }^{40,41}$ to 1 . Precedent for such a reaction comes from a variety of sources. (i) Collmann has previously shown that the reaction of 27 with Vaska's complex provides $[\operatorname{IrCl}(\mathrm{C} \equiv \mathrm{CPh})(\mathrm{HgC} \equiv$ $\left.\mathrm{CPh})(\mathrm{CO})\left(\mathrm{PPh}_{3}\right)_{2}\right]{ }^{42}$ (ii) We have implicated similar oxidative addition processes in the catalytic demercuration of bis(alkynyl)mercurials by $\left[\mathrm{RhCl}(\mathrm{CO})\left(\mathrm{PPh}_{3}\right)_{2}\right]^{28}$ and $\left[\mathrm{Rh}\left(\mathrm{PPh}_{3}\right)_{2}\left([9] \mathrm{aneS}_{3}\right)\right]-$ $\mathrm{PF}_{6}$ ([9]aneS $\mathrm{S}_{3}=1,4,7$-trithiacyclononane). ${ }^{43}$ (iii) Redox transmetalation by bis(alkynyl) mercurials has proven to be a versatile entry into organolanthanide chemistry. ${ }^{44,45}$ (iv) Roper has shown that the $\mathrm{Hg}-\mathrm{C}$ bonds of $\mathrm{Hg}\left(\mathrm{CF}_{3}\right)_{2}$ and $\mathrm{Hg}\left\{\mathrm{C}\left(\mathrm{N}_{2}\right) \mathrm{CO}_{2} \mathrm{Et}\right\}_{2}$ add to $2^{46}$ and $\left[\mathrm{OsCl}(\mathrm{NO})\left(\mathrm{PPh}_{3}\right)_{3}\right],{ }^{47}$ respectively. (v) The bis(tricarbido) complexes $\left[\mathrm{Ru}\left(\mathrm{C} \equiv \mathrm{CC} \equiv \mathrm{W}(\mathrm{CO})_{2} \mathrm{~L}\right)_{2}(\mathrm{CO})_{2}\left(\mathrm{PPh}_{3}\right)_{2}\right]$ $\left(\mathrm{L}=\mathrm{HB}(\mathrm{pz})_{3}, \mathrm{HB}\left(\mathrm{pzMe}_{2}\right)_{3}\right)$ are obtained from the reaction of 1 with $\mathrm{Hg}\left\{\mathrm{C} \equiv \mathrm{CC} \equiv \mathrm{W}(\mathrm{CO})_{2} \mathrm{~L}\right\}_{2} \cdot{ }^{1}$

Treating a solution of $\mathbf{1}$ in toluene with 1 equiv of $\operatorname{Hg}(\mathrm{C} \equiv$ $\mathrm{CPh})_{2}(27)$ results in the formation of an essentially colorless complex formulated as $c c t-\left[\mathrm{Ru}(\mathrm{C} \equiv \mathrm{CPh})(\mathrm{HgC} \equiv \mathrm{CPh})(\mathrm{CO})_{2-}\right.$ $\left.\left(\mathrm{PPh}_{3}\right)_{2}\right](\mathbf{2 8 a})$ in $67 \%$ yield (Scheme 3$)$. Infrared data for 28a include carbonyl absorptions at 2017 and $1971 \mathrm{~cm}^{-1}$ and a $v_{\mathrm{CC}}$ absorption at $2101 \mathrm{~cm}^{-1}$. The former may be compared with those for the closely related complex $\left[\mathrm{Ru}\left(\mathrm{CF}_{3}\right)\left(\mathrm{HgCF}_{3}\right)(\mathrm{CO})_{2-}\right.$ $\left.\left(\mathrm{PPh}_{3}\right)_{2}\right]$ (28b; IR (Nujol) 2018, $\left.1963 \mathrm{~cm}^{-1}\right)\left(\right.$ Table 3), ${ }^{46}$ from which it may be concluded that the alkynyl is similar in field strength to the $\mathrm{CF}_{3}$ ligand. A single, albeit broad and unresolved, carbonyl resonance in the ${ }^{13} \mathrm{C}\left\{{ }^{1} \mathrm{H}\right\}$ NMR spectrum suggests overlap of what should be two unique (triplet) resonances for the chemically distinct $\mathrm{CO}$ ligands. The corresponding resonances in the complex $\left[\mathrm{Ru}(\mathrm{C} \equiv \mathrm{CR})(\mathrm{HgC} \equiv \mathrm{CR})(\mathrm{CO})_{2}\left(\mathrm{PPh}_{3}\right)_{2}\right]$

(39) Given that dissolution of this complex in dichloromethane leads to replacement of the initial infrared absorption $\left(1940 \mathrm{~cm}^{-1}\right)$ by a new one at $1970 \mathrm{~cm}^{-1}$ and that addition of methanol precipitates the original complex, it might be better formulated as $\left[\mathrm{RuCl}_{2}(\mathrm{CO})(\mathrm{MeOH})\left(\mathrm{PPh}_{3}\right)_{2}\right]$ or $\left[\mathrm{RuCl}_{2}\right.$ (CO) $\left.\left(\mathrm{OH}_{2}\right)\left(\mathrm{PPh}_{3}\right)_{2}\right]$.

(40) Methods of Elemento-Organic Chemistry; Nesmeyanov, A. N., Kocheshkov, K. A., Eds.; p 67. North-Holland: Amsterdam, 1967; Vol. 4 (Mercury).

(41) For a discussion of the safety hazards associated with the use of bis(alkynyl) mercurials, see: Dewhurst, R. D.; Hill, A. F.; Smith, M. K. Organometallics 2006, 25, 2388.

(42) Collman, J. P.; Kang, J. W. J. Am. Chem. Soc. 1967, 89, 844.

(43) Hill, A. F.; Wilton-Ely, J. D. E. T. Organometallics 1997, 16, 4517.

(44) (a) Deacon, G. B.; Wilkinson, D. L. Inorg. Chim. Acta 1988, 142, 155. (b) Deacon, G. B.; Koplick, A. J. J. Organomet. Chem. 1978, 146, C43. (c) Deacon, G. B.; Koplick, A. J.; Raverty, W. D.; Vince, D. G. J. Organomet. Chem. 1979, 182, 121. (d) Deacon, G. B.; Koplick, A. J.; Tuong, T. D. Aust. J. Chem. 1982, 35, 941. (e) Deacon, G. B.; Newham, R. H. Aust. J. Chem. 1985, 38, 1757. (f) Deacon, G. B.; Nickel, S.; MacKinnon, P.; Tiekink, E. R. T. Aust. J. Chem. 1990, 43, 1245.

(45) Lin, G.; McDonald, R.; Takats, J. Organometallics 2000, 19, 1814.

(46) Clark, G. R.; Hoskins, S. V.; Roper, W. R. J. Organomet. Chem. 1982, 234, C9.

(47) Gallop, M. A.; Jones, T. C.; Rickard, C. E. F.; Roper, W. R. J. Chem. Soc., Chem. Commun. 1984, 1002.
Scheme 3. Reactions of 1 with $\mathrm{Hg}(\mathrm{C} \equiv \mathrm{CPh})_{2}\left(\mathrm{~L}=\mathrm{PPh}_{3}\right)$

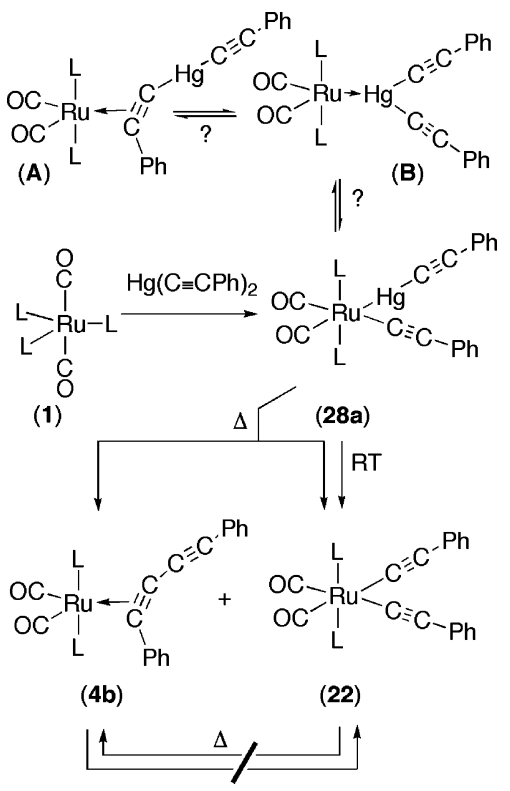

Table 3. IR and ${ }^{31} \mathrm{P}$ NMR Data for $\mathrm{RuR}(\mathrm{HgR})(\mathrm{CO})_{2}\left(\mathrm{PPh}_{3}\right)_{2}{ }^{a}$

\begin{tabular}{lccc}
\hline \multicolumn{1}{c}{$\mathrm{R}$} & $\nu_{\mathrm{CO}}, \mathrm{cm}^{-1}$ & $\delta_{\mathrm{P}}, \mathrm{ppm}$ & ${ }^{2} J_{\mathrm{PHg}}, \mathrm{Hz}$ \\
\hline $\mathrm{CF}_{3}(\mathbf{2 8 b})^{46}$ & 2018,1963 & & \\
$\left.\mathrm{CCPh}^{28 a}\right)$ & 2017,1971 & 36.4 & 392 \\
$\mathrm{C}_{3} \mathrm{~W}(\mathrm{CO})_{2} \mathrm{Tp}(\mathbf{2 8 c})^{1}$ & 2027,1974 & 33.7 & 382 \\
$\mathrm{C}_{3} \mathrm{~W}(\mathrm{CO})_{2} \mathrm{Tp}^{*}(\mathbf{2 8 d})^{1}$ & 2025,1966 & 34.3 & 360
\end{tabular}

${ }^{a} \mathrm{Tp}=\mathrm{HB}(\mathrm{pz})_{3}, \mathrm{Tp}^{*}=\mathrm{HB}\left(\mathrm{pzMe}_{2}\right)_{3}$.

(28c, $\left.\mathrm{R}=\mathrm{C} \equiv \mathrm{W}(\mathrm{CO})_{2}\left\{\mathrm{HB}\left(\mathrm{pzMe}_{2}\right)_{3}\right\}\right)^{1}$ are observed at $\delta_{\mathrm{C}} 200.7$ and 201.5, and hence overlap of the resonances in 28a would appear plausible. The appearance of a single resonance in the ${ }^{31} \mathrm{P}\left\{{ }^{1} \mathrm{H}\right\}$ NMR spectrum further confirms the $c c t$-28a geometry, featuring satellites arising from coupling to mercury $\left({ }^{2} J_{\mathrm{HgP}}(\mathrm{cis})\right.$ $=392 \mathrm{~Hz}$ ). A molecular ion is not observed in the APCI mass spectrum; however, abundant peaks due to $[\mathrm{M}-\mathrm{HgCCPh}]^{+}$ and $[\mathrm{M}-\mathrm{HgCCPh}+\mathrm{MeCN}]^{+}$could be identified by isotopic simulation, suggesting some fragility in the $\mathrm{Ru}-\mathrm{Hg}$ bond.

The complex 28a slowly extrudes mercury in solution at ambient temperature to provide almost exclusively the bis(alkynyl) complex 22. However, heating 28a in refluxing $d_{6}$ benzene results in the deposition of elemental mercury (in

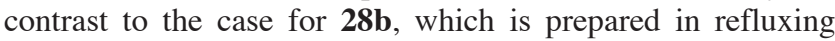
toluene, $45 \mathrm{~min}$ ) and the formation of an approximately $1: 1$ mixture of $\mathbf{4 b}$ and 22 (by ${ }^{31} \mathrm{P}\left\{{ }^{1} \mathrm{H}\right\}$ NMR) (see Scheme 3). As noted above, a range of rhodium complexes will catalyze the demercuration of bis(alkynyl) mercurials to the corresponding diyne, which is liberated from the various rhodium(I) centers. Similar reductive elimination processes have been suggested in the stoichiometric homocoupling of alkynyllithiums by $\left[\mathrm{NiCl}_{2}\left(\mathrm{PPh}_{3}\right)_{2}\right]{ }^{48}$ For such a process to occur, the most plausible intermediate, in the case of $\left[\mathrm{RhCl}(\mathrm{CO})\left(\mathrm{PPh}_{3}\right)_{2}\right]$ would be the $\mathrm{d}^{6}$-octahedral cis-bis(alkynyl) complex $\left[\mathrm{Rh}(\mathrm{C} \equiv \mathrm{CPh})_{2} \mathrm{Cl}(\mathrm{CO})\right.$ $\left(\mathrm{PPh}_{3}\right)_{2}$ ], which would be isoelectronic with 22. However, heating 22 in toluene under reflux does not lead to the reductive elimination of diphenylbutadiyne and neither does it lead to the formation of its structural isomer, the butadiyne complex $\mathbf{4 b}$. Thus, $\mathbf{2 2}$ is not an intermediate in the conversion of $\mathbf{2 8 \mathbf { a }}$ to $\mathbf{4 b}$. Furthermore, although heating $\mathbf{4 b}$ alone in refluxing toluene does produce a plethora of ruthenium phosphine complexes (vide supra), 22 could not be spectroscopically identified among these

(48) Smith, E. H.; Whittal, J. Organometallics 1994, 13, 5169 
${ }^{\left({ }^{1} \mathrm{P}\right.}\left\{{ }^{1} \mathrm{H}\right\}$ NMR). Thus, 4b is not an intermediate in the conversion of $\mathbf{2 8} \mathbf{a}$ to $\mathbf{2 2}$ and an alternative common intermediate needs to be considered. The possibility that the oxidative addition of $\mathbf{2 7}$ is reversible such that mercury extrusion occurs remote from metal followed by $\mathrm{PhC} \equiv \mathrm{CC} \equiv \mathrm{CPh}$ recoordination can be excluded: heating a solution of $\mathbf{2 7}$ in toluene under reflux does not lead to any spectroscopically observable butadiyne or any visible mercury deposition over a period of $24 \mathrm{~h}$. Neither is there any indication that mercury extrusion from $\mathbf{2 7}$ is photolytic ( $24 \mathrm{~h}, d_{6}$-benzene, domestic sunlamp); although a pale yellow color develops, there is no spectroscopically observable diyne formation. Furthermore, repeated cycling of a sample of pure ${ }^{41} 27$ through its melting point does not lead to appreciable decomposition or variation in melting point ( $\mathrm{mp}$ $121-124{ }^{\circ} \mathrm{C}$ ). Thus, we are convinced that the extrusion of mercury from $\mathbf{2 8 a}$ is an intramolecular process. These observations taken together are consistent with two distinct mechanisms for the extrusion of mercury from 28a. The first involves direct extrusion from the linear $\mathrm{Ru}-\mathrm{Hg}-\mathrm{C}$ linkage of 28a to provide 22, a process that operates slowly at room temperature. Such mercury extrusions are implicit in the formation of $\left[\mathrm{Ru}\left(\mathrm{C}_{6} \mathrm{H}_{4}\right.\right.$ $\left.\mathrm{Me}-4) \mathrm{Cl}(\mathrm{CO})\left(\mathrm{PPh}_{3}\right)_{2}\right]$ from $\left[\mathrm{RuHCl}(\mathrm{CO})\left(\mathrm{PPh}_{3}\right)_{3}\right]$ and $\mathrm{Hg}\left(\mathrm{C}_{6} \mathrm{H}_{4}-\right.$ $\mathrm{Me}-4)_{2}$ via the putative intermediate $\left[\mathrm{Ru}\left(\mathrm{HgC}_{6} \mathrm{H}_{4} \mathrm{Me}-4\right) \mathrm{Cl}(\mathrm{CO})\right.$ $\left.\left(\mathrm{PPh}_{3}\right)_{2}\right] .{ }^{49}$ The second mechanism, which only operates significantly at elevated temperatures, is suggested to involve the inner-sphere reductive elimination of $\mathrm{Hg}(\mathrm{C} \equiv \mathrm{CPh})_{2}$, which nevertheless remains bound to the ruthenium center. Two variants on how the mercurial might bind are as a $\pi$ adduct through one $\mathrm{C} \equiv \mathrm{C}$ bond ( $\mathbf{A}$ in Scheme 3 ) or as a $\sigma$ Lewis acid adduct through mercury (B). Either of these would involve geometries that place the alkynyl groups in closer mutual proximity than in the precursor 28a. In support of the somewhat curious intermediate involving a $\mathrm{Ru} \rightarrow \mathrm{Hg}$ interaction, we note that (i) Dixneuf has reported the isolation of a stable $\mathrm{HgCl}_{2}$ adduct of a zerovalent iron carbene complex, ${ }^{50}$ (ii) Lewis base adducts of bis(alkynyl) mercurials have been previously observed, ${ }^{51}$ and (iii) the ability of zerovalent ruthenium and osmium centers to act as Lewis bases has been demonstrated. ${ }^{52,53}$ We suggest that the trigonal coordination geometry may predispose the mercury toward reductive elimination of diyne. We concede that this remains conjecture, with which the observations are nevertheless consistent.

The behavior of $\mathbf{2}$ toward diphenylbutadiyne contrasts markedly with that of $\mathbf{1}$. We find that the cyclopentadienone complex $\left[\mathrm{Ru}\left\{\eta^{4}-\mathrm{O}=\mathrm{CC}_{4} \mathrm{Ph}_{2}(\mathrm{C} \equiv \mathrm{CPh})_{2}\right\}(\mathrm{CO})_{2}\left(\mathrm{PPh}_{3}\right)\right](29)$ is indeed formed when 2 and $\mathrm{PhC} \equiv \mathrm{CC} \equiv \mathrm{CPh}$ are heated in refluxing toluene but that in contrast to previous claims ${ }^{6}$ (i) $\mathrm{CO}_{2}$ is not required for the reaction to proceed and (ii) small amounts of 9 (ca. 10$20 \%$ ) are also obtained. This parallels our findings for the reactions of $\mathbf{1}$ and $\mathbf{2}$ with diphenylacetylene. ${ }^{3}$ Although our measurements of the unit cell of a crystal of $\mathbf{2 9}$ agree with those reported, ${ }^{6}$ we find some inconsistencies in the spectroscopic data. ${ }^{55}$ Our infrared spectrum has three of the reported absorp-

(49) (a) Roper, W. R.; Wright, L. J. J. Organomet. Chem., 1977, 142, C1. (b) Rickard, C. E. F.; Roper, W. R.; Taylor, G. E.; Waters, J. M.; Wright, L. J. J. Organomet. Chem. 1990, 389, 375.

(50) Le Bozec, H.; Dixneuf, P. H.; Adams, R. D. Organometallics 1984, $3,1919$.

(51) Cano, E. M.; Santos, M. A.; Ballester, R. L. Anal. Quim. 1977, 73, 1051.

(52) Davis, H. B.; Einstein, F. W. B.; Glavina, P. G.; Jones, T.; Pomeroy, R. K.; Rushman, P. Organometallics 1989, 8, 1030.

(53) (a) Hill, A. F.; Owen, G. R.; White, A. J. P.; Williams, D. J. Angew. Chem., Int. Ed. 1999, 38, 2759. (b) Foreman, M. R. St.-J.; Hill, A. F.; Owen, G. R.; White, A. J. P.; Williams, D. J. Organometallics 2003, 22, 4446. (c) Foreman, M. R. St.-J.; Hill, A. F.; White, A. J. P.; Williams, D. J. Organometallics 2004, 23, 913.

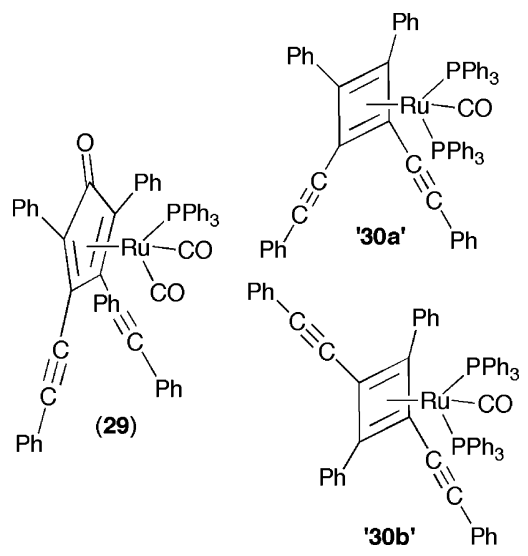

tions (2018, 1966, and $1619 \mathrm{~cm}^{-1}$ ); however, the curiously coincident strong and weak stretches reported at $1928 \mathrm{~cm}^{-1}$ are absent from our spectrum. The ${ }^{31} \mathrm{P}\left\{{ }^{1} \mathrm{H}\right\}$ NMR spectrum of the redissolved crystals of complex $\mathbf{2 9}$ used for the crystallographic study comprises a single resonance at $\delta_{\mathrm{P}} 41.9$, while the original report claims two resonances at $\delta_{\mathrm{P}} 36.4$ and 33.1 due to an inseparable mixture of what was claimed to be two regioisomers of 29 (N.B.: our ruthenacyclopentadiene complex 9 has a single resonance at $\left.\delta_{\mathrm{P}} 36.4\right)$. The published ${ }^{13} \mathrm{C}$ data for the "second isomer" include without explanation two ketonic resonances $\left(\delta_{\mathrm{C}}\right.$ 175.0, 166.3).

The regioselectivity of the phenylacetylide units in $\mathbf{2 9}$ is different from that which would be obtained were $\mathbf{9}$ to be an intermediate in its formation via carbonyl insertion and reductive elimination, and as noted above, $\mathbf{9}$ is stable with respect to either $\mathrm{CO}$ insertion or reductive elimination under the conditions of the formation of 29. Were reductive elimination to occur from 9 (without prior $\mathrm{CO}$ insertion), the product would be the cisbis(phenylethynyl)cyclobutadiene complex $\left[\mathrm{Ru}\left\{\eta^{4}-\mathrm{C}_{4} \mathrm{Ph}_{2}(\mathrm{C} \equiv\right.\right.$ $\left.\mathrm{CPh})_{2}\right\}(\mathrm{CO})_{x}\left(\mathrm{PPh}_{3}\right)_{3-\mathrm{x}}$ ] (“30”, $\left.x=1,2\right)$. Inseparable isomers of such a cyclobutadiene complex have been claimed as further products in the reaction of $\mathbf{2}$ with $\mathrm{PhC} \equiv \mathrm{CC} \equiv \mathrm{CPh} ;{ }^{6}$ however, we note that infrared data reported for the complexes "30" $(x$ $=1$ ) are identical with those we obtained for $9 .{ }^{55}$

The ruthenium(0) compound $\mathbf{4 b}$ does not react with bis(trimethylsilyl)butadiyne in refluxing toluene over 3 days, presumably a reflection of the weak binding of this diyne that was demonstrated for the complex $\mathbf{4 c}$. Thus, the same spectroscopic ( $\left.{ }^{31} \mathrm{P} \mathrm{NMR}\right)$ fingerprint for the plethora of products is obtained as when $\mathrm{Me}_{3} \mathrm{SiC} \equiv \mathrm{CC} \equiv \mathrm{CSiMe}_{3}$ was absent.

Finally, returning to the reported role of $\mathrm{CO}_{2}$ in the "activation" of $\mathbf{2}$, we considered that adventitious oxygen might have been a factor. A recently established mechanism for the conversion of coordinated $\mathrm{CO}$ to $\mathrm{CO}_{2}$ involves the initial conversion of the carbonyl ligand of $\left[\mathrm{OsCl}(\mathrm{NO})(\mathrm{CO})\left(\mathrm{PPh}_{3}\right)_{2}\right]$ to a peroxycarbonyl by reaction with $\mathrm{O}_{2} .{ }^{56}$ When it is heated, the peroxycarbonyl complex behaves differently, depending on whether it is in solution or in the solid state. Thus, as a suspension in refluxing heptane, rearrangement of the peroxycarbonyl to a conventional carbonato complex is observed. However, when the complex is heated in solution in refluxing benzene in the presence of additional phosphine, $\mathrm{CO}_{2}$ and $\mathrm{OPPh}_{3}$

(54) Crossley, I. R.; Foreman, M. R. St.-J.; Hill, A. F.; White, A. J. P.; Williams, D. J. Chem. Commun. 2005, 221.

(55) No explanation was provided for why two different isomers of a monocarbonyl complex give rise to two $v_{\mathrm{CO}}$ IR absorptions (reported, 2011.5 vs, $1955.6 \mathrm{~cm}^{-1}$; cf. 2012, $1956 \mathrm{~cm}^{-1}$ for 9). The $[\mathrm{M}-\mathrm{CO}]^{+}$base peak reported in the FAB-MS spectrum thus corresponds to $[\mathrm{M}-2 \mathrm{CO}]^{+}$.

(56) Clark, G. R.; Laing, K. R.; Roper, W. R.; Wright, A. H. Inorg. Chim. Acta, 2004, 357, 1767 
are liberated to provide [OsCl(NO) $\left.\left(\mathrm{PPh}_{3}\right)_{3}\right]$, thereby converting the substitution-inert complex $\left[\mathrm{OsCl}(\mathrm{NO})(\mathrm{CO})\left(\mathrm{PPh}_{3}\right)_{2}\right]$ into the labile $\left[\mathrm{OsCl}(\mathrm{NO})\left(\mathrm{PPh}_{3}\right)_{3}\right] .^{56,57}$ This pair of complexes in some ways reflect the properties of substitution inert $\mathbf{2}$ and labile $\mathbf{1}$, respectively (the unique properties of nitrosyl ligands notwithstanding). Furthermore, Caulton has also proposed a peroxycarbonyl complex as an intermediate in the oxidation of $\left[\mathrm{Ru}(\mathrm{CO})_{2}\left(\mathrm{PEt}_{3}\right)_{3}\right]$ to provide $\left[\mathrm{Ru}\left(\kappa^{2}-\mathrm{O}_{2} \mathrm{CO}\right)(\mathrm{CO})\left(\mathrm{PEt}_{3}\right)_{3}\right] .{ }^{58} \mathrm{We}$ therefore considered whether oxygen might be serving the same purpose in activating 2.

As noted above, Collman had long since reported that the solid-state reaction of $\mathbf{2}$ with air provided the carbonato complex 8 with infrared absorptions at 2045, 1950, 1890, 1675, and 1635 $\mathrm{cm}^{-1}{ }^{8}$ Infrared data subsequently reported for $\mathbf{8}$ arising from the reaction of $\mathbf{2}$ with alkynes and $\mathrm{CO}_{2}$ only displayed absorptions at 2046, 1982, and $1626 \mathrm{~cm}^{-1}, 6$ clearly at variance with the earlier report. The hydrolysis of $\left[\mathrm{Ru}\left(\mathrm{O}_{2} \mathrm{CN}^{\mathrm{i} P r}\right)_{2}(\mathrm{CO})_{2^{-}}\right.$ $\left(\mathrm{PPh}_{3}\right)_{2}$ ] has since been shown to provide 8 , which was crystallographically characterized as a monohydrate with IR absorptions at 2046, 1982, 1651, and $1626 \mathrm{~cm}^{-1} .59$ Thus, the product obtained from the reaction of $2, \mathrm{PhC} \equiv \mathrm{CC} \equiv \mathrm{CPh}$, and $\mathrm{CO}_{2}$ would indeed appear to be the authentic carbonato complex. However, in apparent contrast to this, Calderazzo has shown ${ }^{59}$ that 2 does not react with $\mathrm{CO}_{2}$ in the presence of $\mathrm{HN}^{\mathrm{i}} \mathrm{Pr}_{2}(5$ atm, $\left.60{ }^{\circ} \mathrm{C}, 10 \mathrm{~h}\right)$. Furthermore, hydrolysis of $\left[\mathrm{Ru}\left(\mathrm{O}_{2} \mathrm{CN}^{\mathrm{i}} \mathrm{Pr}_{2}\right)_{2}-\right.$ $\left.(\mathrm{CO})_{2}\left(\mathrm{PPh}_{3}\right)_{2}\right]$ in the presence of $\mathrm{CO}$ results in reduction to 2 via 8. ${ }^{59}$ Thus, the implication is that Collman's solid-state preparation also included a second component $\left(v_{\mathrm{CO}} 1950,1890\right.$, $1675 \mathrm{~cm}^{-1}$ ) that may well correspond to the peroxycarbonyl complex $\left[\mathrm{Ru}\left(\kappa^{2}-\mathrm{OOCO}\right)(\mathrm{CO})_{2}\left(\mathrm{PPh}_{3}\right)_{2}\right]$. The ketonic $v_{\mathrm{CO}} \mathrm{IR}$ absorption would not appear to be sufficiently diagnostic to distinguish such possibilities, given that the conversion of [OsCl$\left(\kappa^{2}\right.$-OOCO $\left.)(\mathrm{NO})\left(\mathrm{PPh}_{3}\right)_{2}\right]\left(v_{\mathrm{CO}} 1710 \mathrm{~cm}^{-1}\right)$ to the carbonato complex $\left[\mathrm{OsCl}\left(\kappa^{2}-\mathrm{O}_{2} \mathrm{CO}\right)(\mathrm{NO})\left(\mathrm{PPh}_{3}\right)_{2}\right]\left(v_{\mathrm{CO}} 1705 \mathrm{~cm}^{-1}\right)$ is only attended by a very modest shift in frequency. ${ }^{56}$

We have therefore investigated the reaction of $\mathbf{2}$ with oxygen by in situ ${ }^{31} \mathrm{P}$ NMR spectroscopy. At room temperature in $d_{6}$ benzene solution under 1 atm of oxygen an exceedingly slow reaction ensues, whereby after 15 days a mixture of $\mathbf{2}\left(\delta_{\mathrm{P}} 56.3\right)$, the dioxygen adduct $21\left(\delta_{\mathrm{P}} 35.2\right)$, and phosphine oxide $\left(\delta_{\mathrm{P}} 24.9\right)$ is obtained in a ratio of 10:3:2. During this period a minor resonance at $\delta_{\mathrm{P}} 27.5$ grows and decays, reaching a maximum after 2 days but representing no more than $4-5 \%$ of phosphorus present. A resonance due to free $\mathrm{PPh}_{3}$ also grows and decays at a similar rate. This may well correspond to the carbonato complex $\mathbf{8},{ }^{60}$ in which case it may be assumed that liberated phosphine is capable of reducing this to " $\mathrm{Ru}(\mathrm{CO})_{2}\left(\mathrm{PPh}_{3}\right)_{2}$ ", $\mathrm{OPPh}_{3}$, and $\mathrm{CO}_{2}$ (cf. ref 56), the first species being rapidly trapped as 21. Carbon dioxide is a poor ligand for zerovalent ruthenium, ${ }^{59-63}$ as evidenced by the widespread use of $\mathrm{Me}_{3} \mathrm{NO}$

(57) Hill, A. F.; Roper, W. R.; Waters, J. M.; Wright, A. H. J. Am. Chem. Soc. 1983, 105, 5939 .

(58) Ogasawara, M.; Maseras, F.; Gallego-Planas, N.; Kawamura, K.; Ito, K.; Toyota, K.; Streib, W. E.; Komiya, S.; Eisenstein, O.; Caulton, K. G. Organometallics 1997, 16, 1979.

(59) Dell'Amico, D. B.; F. Calderazzo, F.; Labella, L.; Marchetti, F. J. Organomet. Chem. 2000, 596, 144.

(60) Complex 8 has been reported ${ }^{59}$ to have a single ${ }^{31} \mathrm{P}$ resonance at $\delta_{\mathrm{P}}$ 28.0 in methanol.

(61) $\mathrm{CS}_{2}$, however, reacts with $\mathbf{1}$ to provide the simple $\pi$ adduct [Ru$\left.(\mathrm{SCS})(\mathrm{CO})_{2}\left(\mathrm{PPh}_{3}\right)_{2}\right],{ }^{62}$ and a similar adduct $\left[\mathrm{Ru}(\mathrm{SCO})(\mathrm{CO})_{2}\left(\mathrm{PPh}_{3}\right)_{2}\right]$ is obtained with COS; however, excess COS converts this to the dithiocarbonato- $S, S^{\prime}$ complex $\left[\mathrm{Ru}\left(\mathrm{S}_{2} \mathrm{CO}\right)(\mathrm{CO})_{2}\left(\mathrm{PPh}_{3}\right)_{2}\right] .{ }^{63}$

(62) (a) Grundy, K. R.; Harris, R. O.; Roper, W. R. J. Organomet. Chem. 1975, 90, C34. (b) Clark, G. R.; Collins, T. J.; James, S. M.; Roper, W. R. J. Organomet. Chem. 1977, 125, C23. (c) Boniface, S. M.; Clark, G. R. J. Organomet. Chem. 1980, 184, 125.

(63) Gaffney, T. R.; Ibers, J. A. Inorg. Chem. 1982, 21, 2851. to remove carbonyl ligands from ruthenium carbonyl clusters through oxidative conversion to $\mathrm{CO}_{2}$ (e.g., in the synthesis of $\mathbf{1 1}^{14}$ ). The reaction of 2 with $\mathrm{PhC} \equiv \mathrm{CC} \equiv \mathrm{CPh}$ under ambient conditions was next investigated and found to proceed extremely slowly at room temperature. Over a period of 7 days ca. $16 \%$ conversion to $\mathbf{4 b}$ was observed in addition to $2-3 \%$ of an unidentified compound with $\delta_{\mathrm{P}} 40.7$. Gentle photolysis of the same mixture (domestic sunlamp) resulted in a complete consumption of $\mathbf{2}$ and formation of a 1:1 mixture of $\mathbf{4 b}$ and the unknown compound. Remarkably, when $\mathbf{2}$ and $\mathrm{PhC} \equiv \mathrm{CC} \equiv \mathrm{CPh}$ were combined in $d_{6}$-benzene under an atmosphere of oxygen, there was a dramatic acceleration in the consumption of $\mathbf{2}$ such that after 6 days phosphine oxide accounted for $90 \%$ of phosphorus-containing material, with a further $6 \%$ being due to the dioxygen adduct $\mathbf{2 1}$. We have not characterized the phosphine-free ruthenium-containing products; the ruthenium cluster chemistry of 1,3-diynes is complex ${ }^{14,17 \mathrm{k}, 64}$ and is beyond the scope of this discussion but has been reviewed recently. ${ }^{9}$ What needs to be accounted for is the synergic effect of these two reagents in stripping phosphine from a complex that is generally considered to be inert toward ligand dissociation. We have attempted to rationalize these observations by considering the mechanistic manifold presented in Scheme 1. This assumes that distinct equilibria exist between $\mathbf{2}$ and the coordinatively unsaturated species " $\mathrm{Ru}(\mathrm{CO})_{3}\left(\mathrm{PPh}_{3}\right)$ " and, to a lesser extent, "Ru(CO) $)_{2}\left(\mathrm{PPh}_{3}\right)_{2}$ ". The latter would explain the, albeit exceedingly slow, conversion of $\mathbf{2}$ to $\mathbf{4 b}$ in the presence of diyne and absence of oxygen. The former species, which is more prevalent at higher temperatures, would account for the formation of the cyclopentadienone complexes $\mathbf{5}$ and $\mathbf{2 9}$, in reactions that parallel the observations of Takats and Caulton concerning the lability of complexes of the form $\left[\mathrm{M}(\eta\right.$-alkyne $\left.)(\mathrm{CO})_{3}(\mathrm{~L})\right](\mathrm{M}=\mathrm{Fe}, \mathrm{Ru}$, Os; alkyne $=\mathrm{HC} \equiv \mathrm{CH}, \mathrm{F}_{3} \mathrm{CC} \equiv \mathrm{CCF}_{3} ; \mathrm{L}=\mathrm{CO}, \mathrm{PMe}_{3}, \mathrm{PPh}_{3}$, $\left.\mathrm{PCy}_{3}, \mathrm{P}(\mathrm{OPh})_{3}\right){ }^{65}$ The following borrows heavily from their conclusions; however, the principles are worth restating. A key inference from these studies is that stabilizing "four-electron donor" alkyne behavior, which underpins the wealth of $\mathrm{d}^{4}$ octahedral alkyne chemistry, ${ }^{66}$ can destabilize complexes with higher d occupancies. Thus for $\mathrm{d}^{n}(n \geq 6)$, all " $\mathrm{t}_{2 \mathrm{~g}}$-type" orbitals are fully occupied, resulting in a four-electron conflict with any potentially $\pi$ basic ligands. An implication of this is that "unwelcome" four-electron donation by an alkyne in such systems will be ameliorated by $\pi$ acidic coligands, able to withdraw excessive electron density: i.e., phosphines become labilized while CO ligands become more tightly bound.

We may assume that the initial stages in the disparate reactions of $\mathbf{1}$ and $\mathbf{2}$ with alkynes involve the formation of the complexes $\left[\mathrm{Ru}\left(\eta^{2}-\mathrm{RC} \equiv \mathrm{CR}\right)(\mathrm{CO})_{2}\left(\mathrm{PPh}_{3}\right)_{2}\right]\left(\mathrm{R} \neq \mathrm{H}^{67}\right)(4)$ and $\left[\mathrm{Ru}\left(\eta^{2}-\mathrm{RC} \equiv \mathrm{CR}\right)(\mathrm{CO})_{3}\left(\mathrm{PPh}_{3}\right)\right]$, respectively, and that in each case incipient $\pi$ donation will destabilize phosphine coordination relative to the carbonyl ligands. Thus, phosphine dissociation

(64) (a) Aime, S.; Betancello, R.; Busetti, V.; Gobetto, R.; Granozzi, G.; Osella, D. Inorg. Chem. 1986, 25, 4004. (b) Rivomanana, S.; Lavigne, G.; Lugan, N.; Bonnet. J.-J. Inorg. Chem. 1991, 30, 4110. (c) Rivomanana, S.; Lavigne, G.; Lugan, N; Bonnet. J.-J. Organometallics 1991, 10, 2285. (d) Rivomanana, S.; Lavigne, G.; Lugan, N; Bonnet. J.-J.; Yanez, R.; Mathieu, R. J. Am. Chem. Soc. 1989, 111, 8959. (e) Deeming, A. J.; Felix, M. S. B.; Bates, P. A.; Hursthouse, M. B. J. Chem. Soc., Dalton Trans. 1987, 461

(65) (a) Pearson, J.; Cooke, J.; Takats, J.; Jordan, R. B. J. Am. Chem. Soc. 1998, 120, 1434. (b) Mao, T.; Zhang, Z.; Washington, J.; Takats, J.; Jordan, R. B. Organometallics 1999, 18, 2331. (c) Gagné, M. R.; Takats, J. Organometallics 1988, 7, 6850. (d) Burn, M. J.; Kiel, G.-Y.; Seils, F.; Takats, J.; Washington, J. J. Am. Chem. Soc. 1989, 111, 6850. (e) Marinelli, G.; Streib, W. E.; Huffman, J. C.; Caulton, K. G.; Gagné, M. R.; Takats, J.; Dartiguenave, M.; Chardon, C.; Jackson, S. A.; Eisenstein, O. Polyhedron 1990, 9, 1867-1881.

(66) Templeton, J. L. Adv. Organomet. Chem. 1989, 29, 1. 
from either intermediate and coordination of a second alkyne would provide $\left[\mathrm{Ru}(\mathrm{RC} \equiv \mathrm{CR})_{2}(\mathrm{CO})_{2}\left(\mathrm{PPh}_{3}\right)\right]$ and $\left[\mathrm{Ru}(\mathrm{RC} \equiv \mathrm{CR})_{2}-\right.$ $\left.(\mathrm{CO})_{3}\right]$, respectively. In general, the presence of strongly $\pi$ acidic coligands promotes migratory insertion, such that the latter would be more prone than the former to migratory insertion of carbonyl and alkyne ligands. Precedent for this type of coupling and its encouragement by $\pi$ acid coordination is provided by the isolation of the osmacyclobutenethione $\left[\mathrm{Os}\left\{\kappa^{2}-\mathrm{C}(=\mathrm{S}) \mathrm{CPh}=\right.\right.$ $\left.\mathrm{CPh}\}(\mathrm{CO})_{2}\left(\mathrm{PPh}_{3}\right)_{2}\right]$ upon carbonylation of the alkyne complex $\left[\mathrm{Os}(\eta-\mathrm{PhC} \equiv \mathrm{CPh})(\mathrm{CS})\left(\mathrm{PPh}_{3}\right)_{2}\right]{ }^{68}$ The former $\left(\left[\mathrm{Ru}(\eta-\mathrm{RC} \equiv \mathrm{CR})_{2^{-}}\right.\right.$ $\left.\left.(\mathrm{CO})_{2}\left(\mathrm{PPh}_{3}\right)\right]\right)$, in contrast, enters into alkyne coupling to form a ruthenacyclopenta-1,3,5-triene that may be stabilized by readdition of phosphine to relocalize the metallacycle bonding to a ruthenacyclopenta-2,4-diene. The possibility that the $\alpha$-alkynyl substituent might also serve this role is suggested (vide infra), supported by the observation of such an interaction in the zirconacyclopentadiene $\mathbf{1 9}^{19 \mathrm{~b}}$ and the demonstrated hemilability of $\alpha$-alkynyl-substituted vinyl ligands. ${ }^{69}$

The regioselectivity observed in formation of the $\alpha, \alpha^{\prime}$-bis(alkynyl) isomer of the ruthenacyclopentadiene 9 and the alternative regiochemistry of the 3,4-bis(ethynyl) isomer of the cyclopentadienone complex $\mathbf{2 9}$ may be rationalized as follows. The first step in the construction of the cyclopentadienone most likely involves carbonyl/alkyne coupling. This may be viewed as a migratory insertion of one of the $\mathrm{Ru}-\mathrm{C}^{\delta-}$ bonds of a "metallacyclopropene" type of alkyne onto one coordinated ${ }^{\delta+} \mathrm{CO}$. In this case of the two available $\mathrm{Ru}-\mathrm{C}$ carbons, that bearing the phenyl substituent will be more electron-rich than that with the electron-withdrawing alkynyl substituents, such that the latter remains remote from the carbonyl. The insertion of the second alkyne into the resulting vinyl ligand simply follows the steric distinction between $\mathrm{Ph}$ and $\mathrm{CCPh}$ substituents. The origins of the regiochemistry associated with $\mathbf{9}$ are less clear. However, one possibility is that the alkynyl groups are not entirely innocent but perhaps coordinate weakly to the ruthenium center during the approach to the $\mathrm{C}-\mathrm{C}$ bond-forming transition state, thereby lowering the energy associated with development of coordinative unsaturation - a role not as effectively served by the phenyl substituents. We have previously discussed the operation of hemilabile $\alpha$-alkynyl coordination in the chemistry of the cationic complex $\left[\mathrm{Ru}\left\{\eta^{3}-\mathrm{C}(\mathrm{C} \equiv \mathrm{CPh})=\mathrm{CHPh}\right\}(\mathrm{CO})_{2^{-}}\right.$ $\left.\left(\mathrm{PPh}_{3}\right)_{2}\right]^{+}$obtained upon protonation of $\mathbf{4 b} .^{2,69}$

\section{Conclusions}

The product of the thermal reaction of $\mathbf{1}$ with excess diphenylbutadiyne is a ruthenacyclopentadiene, while the same reaction with diphenylacetylene yields a completely unrelated product involving a coordinated indenone ligand. In contrast, the reactions of $\mathbf{2}$ with both alkynes proceed via $[2+2+1]$ cycloaddition to give coordinated cyclopentadienones. The disparate reactivity on the part of complexes $\mathbf{1}$ and $\mathbf{2}$, which differ only by replacement of one $\mathrm{PPh}_{3}$ with $\mathrm{CO}$, has been interpreted in terms of the relative lability of $\mathrm{CO}$ and $\mathrm{PPh}_{3}$. Thus, both complexes appear to dissociate a $\mathrm{PPh}_{3}$ ligand (1 spontaneously and $\mathbf{2}$ on heating) to generate " $\mathrm{Ru}(\mathrm{CO})_{2}\left(\mathrm{PPh}_{3}\right)_{2}$ " and " $\mathrm{Ru}$ $(\mathrm{CO})_{3}\left(\mathrm{PPh}_{3}\right)$ " in solution, respectively, the distinct electronic properties of which impinge on the reactivity of alkynes that subsequently coordinate. We find no evidence for the formation

(67) In the case of terminal alkynes, oxidative addition of the alkyne occurs to provide $\left[\mathrm{RuH}(\mathrm{C} \equiv \mathrm{CR})(\mathrm{CO})_{2}\left(\mathrm{PPh}_{3}\right)_{2}\right]$ : Bartlett, M. J.; Hill, A. F.; Smith, M. K. Organometallics 2005, 24, 5795.

(68) Elliott, G. P.; Roper, W. R. J. Organomet. Chem. 1983, 250 , C5. (69) Hill, A. F.; Melling, R. P.; Thompsett, A. R. J. Organomet. Chem., 1991, 402, C8. or existence of the complexes previously formulated as cyclobutadiene adducts 1,2 - and $1,3-\left[\mathrm{Ru}\left\{\eta^{4}-\mathrm{C}_{4} \mathrm{Ph}_{2}(\mathrm{C} \equiv \mathrm{CPh})_{2}\right\}(\mathrm{CO})\right.$ $\left.\left(\mathrm{PPh}_{3}\right)_{2}\right]$, noting that some of the published spectroscopic data ${ }^{6}$ correspond to the ruthenacyclopentadiene complex $\mathbf{9}$. While 9 might appear to be a plausible intermediate en route to the proposed cyclobutadiene complexes, this transformation does not ensue under the reported reaction conditions.

\section{Experimental Section}

General Procedures. All air-sensitive manipulations were carried out under a dry, oxygen-free nitrogen atmosphere using standard Schlenk and vacuum manifold techniques or in an argon filled drybox, using dried and degassed solvents. NMR spectra were recorded on a Varian Inova $300\left({ }^{1} \mathrm{H}\right.$ at $300.75 \mathrm{MHz},{ }^{13} \mathrm{C}$ at 75.4 $\mathrm{MHz},{ }^{31} \mathrm{P}$ at $121.4 \mathrm{MHz}$ ) instrument. The chemical shifts $(\delta)$ for ${ }^{1} \mathrm{H}$ and ${ }^{13} \mathrm{C}\left\{{ }^{1} \mathrm{H}\right\}$ spectra are given in ppm relative to residual signals of the solvent and for ${ }^{31} \mathrm{P}\left\{{ }^{1} \mathrm{H}\right\}$ spectra relative to an external $85 \%$ $\mathrm{H}_{3} \mathrm{PO}_{4}$ reference. The coupling constants $(J)$ are given in $\mathrm{Hz}$ with an estimated error of $\pm 0.5 \mathrm{~Hz}$. Virtual triplet ${ }^{13} \mathrm{C}$ resonances for the trans- $\mathrm{Ru}\left(\mathrm{PPh}_{3}\right)_{2}$ phenyl groups are indicated by "vt" with apparent $J_{\mathrm{PC}}$ couplings given. Mass spectra of the complexes were obtained on a Micromass ZMD spectrometer using the APCI technique in acetonitrile by the Mass Spectrometry service of the Research School of Chemistry, Australian National University. The microanalyses were carried out by the microanalytical service of the Research School of Chemistry, Australian National University. The synthesis of compounds $\left[\mathrm{Ru}(\mathrm{CO})_{2}\left(\mathrm{PPh}_{3}\right)_{3}\right](\mathbf{1}){ }^{4,70}\left[\mathrm{Ru}(\mathrm{CO})_{3^{-}}\right.$ $\left.\left(\mathrm{PPh}_{3}\right)_{2}\right](\mathbf{2}),{ }^{71}\left[\mathrm{Ru}\left(\mathrm{O}_{2}\right)(\mathrm{CO})_{2}\left(\mathrm{PPh}_{3}\right)_{2}\right](\mathbf{2 1}),{ }^{4}\left[\mathrm{Ru}\left(\eta^{2}-\mathrm{PhC} \equiv \mathrm{CC} \equiv \mathrm{CPh}\right)-\right.$ $\left.(\mathrm{CO})_{2}\left(\mathrm{PPh}_{3}\right)_{2}\right](\mathbf{4 b}),{ }^{2}\left[\mathrm{Ru}\left(\mathrm{C}_{2} \mathrm{H}_{4}\right)(\mathrm{CO})_{2}\left(\mathrm{PPh}_{3}\right)_{2}\right] \quad(\mathbf{2 0}),{ }^{4} \quad[\mathrm{RuH}(\mathrm{C} \equiv$ $\left.\mathrm{CPh})(\mathrm{CO})\left(\mathrm{PPh}_{3}\right)_{3}\right],{ }^{31}$ and $\mathrm{Hg}(\mathrm{C} \equiv \mathrm{CPh})_{2}{ }^{40}$ have been described previously, while diynes were obtained from commercial sources. Alkynyl mercurials should be treated as potentially explosive and appropriate precautions taken. ${ }^{41}$ N.B.: chlorinated solvents such as $\mathrm{CHCl}_{3}$ are inappropriate for investigations involving $\mathbf{1}\left(\delta_{\mathrm{P}}\right.$ $\left.\left(\mathrm{CDCl}_{3}\right) 57.70\right)$, due to the rapid formation of $\left[\mathrm{RuCl}_{2}(\mathrm{CO})_{2}\left(\mathrm{PPh}_{3}\right)_{2}\right]$ $\left(\delta_{\mathrm{P}}\left(\mathrm{CDCl}_{3}\right)\right.$ 17.57). The reaction with $\mathrm{CH}_{2} \mathrm{Cl}_{2}$ is somewhat slower, allowing some rapid reactions to be carried out in that solvent.

The structures of the four compounds $4 \mathbf{b}, \mathbf{9}, \mathbf{2 2}$, and 25a each showed interesting crystallographic features. The constrained leastsquares refinement program RAELS2000 ${ }^{72}$ was used for the refinement of all four structures, as it allowed sensitive control of the refinements using appropriate parametrizations. Extra details of these refinements that included rigid-body TLX parametrizations and the use of refinable local coordinates relative to refinable local orthonormal axial systems ${ }^{73}$ may be obtained from the CIF files in the Supporting Information.

Synthesis of $\left[\mathbf{R u}\left(\kappa^{2}-\mathrm{CR}=\mathrm{CPhCPh}=\mathrm{CR}\right)(\mathrm{CO})_{2}\left(\mathrm{PPh}_{3}\right)_{2}\right](\mathbf{9}, \mathbf{R}$ $=\mathbf{C C P h})$. A mixture of $\left[\mathrm{Ru}(\mathrm{CO})_{2}\left(\mathrm{PPh}_{3}\right)_{3}\right](\mathbf{1} ; 0.40 \mathrm{~g}, 0.42 \mathrm{mmol})$ and diphenylbutadiyne $(0.26 \mathrm{~g}, 1.27 \mathrm{mmol})$ was heated anaerobically under reflux in toluene $(80 \mathrm{~mL})$, resulting in a color change to dark orange. The reaction progress was followed by infrared and ${ }^{31} \mathrm{P}\left\{{ }^{1} \mathrm{H}\right\}$ NMR spectroscopy, and after 3 days at reflux, no further product was formed. The toluene was removed under reduced pressure, and the orange-brown residue was washed with diethyl ether. Recrystallization from toluene/hexane or THF/diethyl ether yielded orange crystals $(0.36 \mathrm{~g}, 79 \%)$. Anal. Found: C, 76.92; $\mathrm{H}, 4.81 ; \mathrm{P}, 5.65$. Calcd for $\mathrm{C}_{70} \mathrm{H}_{50} \mathrm{O}_{2} \mathrm{P}_{2} \mathrm{Ru}$ : C, 77.41; H, 4.64; $\mathrm{P}$, 5.70. Mp: $210-212{ }^{\circ} \mathrm{C} .{ }^{1} \mathrm{H}$ NMR $(298 \mathrm{~K}, 300 \mathrm{MHz}) \mathrm{C}_{6} \mathrm{D}_{6}: \delta$ 7.97-7.91 (m, $12 \mathrm{H}), 7.30,7.27(\mathrm{~s} \times 2,4 \mathrm{H}), 7.09-6.90(\mathrm{~m}, 30$ $\mathrm{H}), 6.68,6.66(\mathrm{~s} \times 2,4 \mathrm{H}) .{ }^{13} \mathrm{C}\left\{{ }^{1} \mathrm{H}\right\} \mathrm{NMR}(298 \mathrm{~K}, 75 \mathrm{MHz})$ : in

(70) Hill, A. F.; Tocher, D. A.; White, A. J. P.; Williams, D. J.; WiltonEly, J. D. E. T. Organometallics 2005, 24, 5342.

(71) Collman, J. P.; Roper, W. R. J. Am. Chem. Soc. 1965, 87, 4008 (72) (a) Rae, A. D. RAELS2000; Australian National University, Canberra, Australia, 2000. (b) Rae, A. D.; Edwards, A. J. Proceedings, 20th European Crystallography Conference; Cracow, Poland, 2001; p 147.

(73) Rae, A. D. Acta Crystallogr., Sect. A 1975, A31, 570. 
$\mathrm{C}_{6} \mathrm{D}_{6}, \delta_{\mathrm{C}} 200.1(\mathrm{br}, \mathrm{CO}), 164.6(\mathrm{RuC}=\mathrm{C}), 142.3(\mathrm{RuC}=C), 134.8$ $\left(\mathrm{vt}, J_{\mathrm{CP}}=5.5, \mathrm{C}^{2,6}\left(\mathrm{PC}_{6} \mathrm{H}_{5}\right)\right), 134.2\left(\mathrm{vt}, J_{\mathrm{PC}}=23.2, \mathrm{C}^{1}\left(\mathrm{PC}_{6} \mathrm{H}_{5}\right)\right)$, $129.9\left(\mathrm{C}_{4}\left(\mathrm{PC}_{6} \mathrm{H}_{5}\right)\right), 131.5,130.6,129.3\left(\mathrm{C}^{2,3,5,6}\left(\mathrm{CC}_{6} \mathrm{H}_{5}\right)\right)$, remaining $\mathrm{C}_{6} \mathrm{H}_{5}$ peaks obscured by $\mathrm{C}_{6} \mathrm{D}_{6}, 103.7,103.0(\mathrm{C} \equiv \mathrm{C})$; in $\mathrm{CD}_{2} \mathrm{Cl}_{2}, \delta_{\mathrm{C}}$ 199.8 (br, CO), $164.1(\mathrm{RuC}=\mathrm{C}), 142.3(\mathrm{RuC}=C)), 134.7\left(\mathrm{vt}, J_{\mathrm{PC}}\right.$ $=5.5), 133.9\left(\mathrm{vt}, J_{\mathrm{PC}}=23.1, \mathrm{C}^{1}\left(\mathrm{PC}_{6} \mathrm{H}_{5}\right)\right), 128.0\left(\mathrm{vt}, J_{\mathrm{PC}}=4.8\right.$, $\left.\mathrm{C}^{3,5}\left(\mathrm{PC}_{6} \mathrm{H}_{5}\right)\right), 130.0\left(\mathrm{C}^{4}\left(\mathrm{PC}_{6} \mathrm{H}_{5}\right)\right), 131.1,130.1,128.3,126.3$ $\left(\mathrm{C}^{2,3,5,6}\left(\mathrm{CC}_{6} \mathrm{H}_{5}\right)\right), 126.5,125.1\left(\mathrm{C}^{4}\left(\mathrm{CC}_{6} \mathrm{H}_{5}\right)\right), 126.8\left(\mathrm{C}^{1}\left(\mathrm{CC}_{6} \mathrm{H}_{5}\right)\right)$, 103.5, $102.6(\mathrm{C} \equiv \mathrm{C})$. N.B.: free $\mathrm{PhC} \equiv \mathrm{CC} \equiv \mathrm{CPh}$ has $\delta_{\mathrm{C}} 73.9$ and 81.5 for $\mathrm{C} \equiv \mathrm{C} .{ }^{31} \mathrm{P}\left\{{ }^{1} \mathrm{H}\right\}$ NMR $(298 \mathrm{~K}, 121 \mathrm{MHz})$ : in $\mathrm{C}_{6} \mathrm{D}_{6}, \delta_{\mathrm{P}} 36.4$ (s); in $\mathrm{CD}_{2} \mathrm{Cl}_{2}, \delta_{\mathrm{P}}$ 36.2. IR: in Nujol, $2144(\mathrm{C} \equiv \mathrm{C}), 2012,1956$ (CO), $1592(\mathrm{C}=\mathrm{C}) \mathrm{cm}^{-1}$; in toluene, $2151(\mathrm{C} \equiv \mathrm{C}), 2017,1960$ $(\mathrm{CO}), 1594(\mathrm{C}=\mathrm{C}) \mathrm{cm}^{-1}$. MS (APCI+): $1124.2[\mathrm{M}+\mathrm{Na}+\mathrm{O}]$, $1096[\mathrm{M}+\mathrm{Na}+\mathrm{O}-\mathrm{CO}], 834\left[\mathrm{M}-\mathrm{PPh}_{3}-\mathrm{CO}+\mathrm{Na}+\mathrm{O}\right]$. Crystal data for 9: $\mathrm{C}_{70} \mathrm{H}_{50} \mathrm{O}_{2} \mathrm{P}_{2} \mathrm{Ru}, M_{\mathrm{w}}=1086.11$, monoclinic, $P 2_{1} / a$ (No. 14), $a=11.8422(3) \AA, b=44.1243(9) \AA, c=21.2472$ (6) $\AA, \beta=91.373(1)^{\circ}, V=11099.1(5) \AA,{ }^{3} Z=8, \rho_{\text {calcd }}=1.300$ $\mathrm{Mg} \mathrm{m}^{-3}, T=200(2) \mathrm{K}, 10359$ independent measured reflections, $\mathrm{R} 1=0.075, \mathrm{wR}_{2}=0.106,3447$ absorption-corrected reflections $\left(I>3 \sigma(I), 2 \theta \leq 40^{\circ}\right), 380$ parameters. Compound 9 crystallized in space group $P 2_{1} / a$ as a very thin needle and was 0.521(5):0.479 twinned. Only $34 \%$ of the Mo K $\alpha$ reflection data to $2 \theta=40^{\circ}$ could be reliably measured, requiring sensible constraints to simulate an anisotropic refinement. The structure can be described as displacive modulation of an idealized Pcab (space group No. 61) structure with 8 molecules per unit cell. The two Ru atoms in the asymmetric unit are related by the pseudo $c$ glide $0.38-x, y, 1 / 2+z$. For $P c a b$ this operation would be $1 / 2-x, y, 1 / 2+z$. Synthetic precession patterns obtained from the CCD diffraction images showed that the twin plane was normal to $c^{*}$ and may be described as a $b$ glide perpendicular to $c^{*}$ at $z=1 / 2$. Twin related reflections were separated along $c^{*}$ in reciprocal space, and $p_{\mathrm{j}}$ is a function of the $h$ reflection index. Refined values are detailed under _refine special_details in the CIF file. The overall refinement used 380 variables to define the twin overlap and 150 non-H atom positions (CCDC 622358).

Synthesis of $\left[\mathrm{Ru}(\mathrm{C} \equiv \mathbf{C P h})_{2}(\mathrm{CO})_{2}\left(\mathrm{PPh}_{3}\right)_{2}\right] \quad$ (22). Lithium phenylacetylide was prepared by adding ${ }^{n} \mathrm{BuLi}(1.60 \mathrm{~mL}, 1.6$ moldm $\left.{ }^{-3}, 2.66 \mathrm{mmol}\right)$ to a THF $(20 \mathrm{~mL})$ solution of $\mathrm{HC} \equiv \mathrm{CPh}(0.29$ $\mathrm{mL}, 0.27 \mathrm{~g}, 2.66 \mathrm{mmol})$ at $-78{ }^{\circ} \mathrm{C}$ and warming the solution room temperature with stirring. The $c c t$ isomer of $\left[\mathrm{RuCl}_{2}(\mathrm{CO})_{2}\left(\mathrm{PPh}_{3}\right)_{2}\right]$ (23; $0.50 \mathrm{~g}, 0.66 \mathrm{mmol}$ ) (prepared by bubbling $\mathrm{CO}$ through a solution of $\left[\mathrm{RuCl}_{2}\left(\mathrm{PPh}_{3}\right)_{3}\right]$ and then warming in dichloromethane) was weighed into a separate Schlenk flask equipped with a magnetic stirrer bar and suspended in THF $(50 \mathrm{~mL})$. A dark red lithium acetylide solution was added, and the mixture was heated to reflux. After $30 \mathrm{~min}$ at reflux, the ${ }^{31} \mathrm{P}\left\{{ }^{1} \mathrm{H}\right\}$ NMR and infrared spectra indicated complete conversion to the product. The solvent was removed under reduced pressure, and the product was extracted into dichloromethane. Cooling resulted in the precipitation of a small amount of $\mathrm{LiCl}$, which was removed by filtration through diatomaceous earth. Hexane was layered onto the solution, leading to the precipitation of the product as a pale yellow powder. Yield: $0.28 \mathrm{~g}(48 \%) \mathrm{Mp}: 218-220{ }^{\circ} \mathrm{C}$. Anal. Found: C, $72.11 ; \mathrm{H}, 4.63$; $\mathrm{P}$, 6.23. Calcd for $\mathrm{C}_{54} \mathrm{H}_{40} \mathrm{O}_{2} \mathrm{P}_{2} \mathrm{Ru} \cdot \mathrm{H}_{2} \mathrm{O}$ (by IR and ${ }^{1} \mathrm{H}$ NMR integration): $\mathrm{C}, 71.91 ; \mathrm{H}, 4.69 ; \mathrm{P}, 6.87 .{ }^{1} \mathrm{H}$ NMR $(298 \mathrm{~K}, 300$ $\mathrm{MHz})$ : in $\mathrm{CDCl}_{3}, \delta 8.10-8.07\left(\mathrm{~m}, 12 \mathrm{H}, \mathrm{PC}_{6} \mathrm{H}_{5}\right), 7.35-7.33(\mathrm{~m}$, $\left.18 \mathrm{H}, \mathrm{PC}_{6} \mathrm{H}_{5}\right), 7.02-6.99\left(\mathrm{~m}, 6 \mathrm{H}, \mathrm{CC}_{6} \mathrm{H}_{5}\right), 6.72-6.69(\mathrm{~m}, 4 \mathrm{H}$, $\left.\mathrm{CC}_{6} \mathrm{H}_{5}\right) \cdot{ }^{13} \mathrm{C}\left\{{ }^{1} \mathrm{H}\right\}$ NMR $(298 \mathrm{~K}, 75 \mathrm{MHz})$ : in $\mathrm{CDCl}_{3}, \delta 134.8$ (vt, $\left.{ }^{1} J_{\mathrm{CP}}=24, \mathrm{C}^{1}\left(\mathrm{PC}_{6} \mathrm{H}_{5}\right)\right), 134.7\left(\mathrm{C}^{1}\left(\mathrm{CC}_{6} \mathrm{H}_{5}\right)\right), 134.2\left(\mathrm{vt}, J_{\mathrm{CP}}=5.3\right.$, $\left.\mathrm{C}^{2,6}\left(\mathrm{PC}_{6} \mathrm{H}_{5}\right)\right), 130.3,127.5$. $124.5\left(\mathrm{C}^{2-6}\left(\mathrm{CC}_{6} \mathrm{H}_{5}\right)\right), 129.80\left(\mathrm{C}^{4}-\right.$ $\left.\left(\mathrm{PC}_{6} \mathrm{H}_{5}\right)\right), 127.9\left(\mathrm{vt}, J_{\mathrm{CP}}=4.9, \mathrm{C}^{3,5}\left(\mathrm{PC}_{6} \mathrm{H}_{5}\right)\right), 114.4(\mathrm{C} \equiv \mathrm{C}), 107.6$ $(\mathrm{C} \equiv \mathrm{C})$; RuCO resonance not located. ${ }^{31} \mathrm{P}\left\{{ }^{1} \mathrm{H}\right\}$ NMR $(298 \mathrm{~K}, 121$ $\mathrm{MHz}$ ): in $\mathrm{C}_{6} \mathrm{D}_{6}, \delta_{\mathrm{P}} 27.85$; in $\mathrm{CDCl}_{3}, \delta_{\mathrm{P}} 28.18$. IR (THF): 2108 $(\mathrm{C} \equiv \mathrm{C}), 2045,1996(\mathrm{CO}) \mathrm{cm}^{-1}$. MS (APCI+): $920\left[\mathrm{M}+2 \mathrm{H}_{2} \mathrm{O}\right]$, $906[\mathrm{M}+\mathrm{Na}]$. Crystal data for "22" (N.B. the structure was modeled as comprising ca. $10 \%$ of $\left.\mathbf{2 4 a} \cdot \mathrm{CHCl}_{3}\right):\left(\mathrm{C}_{54} \mathrm{H}_{40} \mathrm{O}_{2} \mathrm{P}_{2^{-}}\right.$
$\mathrm{Ru})_{0.894}\left(\mathrm{C}_{47} \mathrm{H}_{36} \mathrm{Cl}_{4} \mathrm{O}_{2} \mathrm{P}_{2} \mathrm{Ru}\right)_{0.106}, M_{\mathrm{w}}=889.56$, monoclinic, $P 2_{1} / n$ (No. 14), $a=10.2783(1) \AA, b=18.7156(2) \AA, c=22.5047(3) \AA$, $\beta=97.566(1)^{\circ}, V=4291.42(8) \AA{ }^{3} Z=4, \rho_{\text {calcd }}=1.377 \mathrm{Mg}$ $\mathrm{m}^{-3}, T=200(2) \mathrm{K}, 7555$ independent measured reflections, $\mathrm{R} 1=$ $0.041, \mathrm{wR} 2=0.061,5330$ absorption-corrected reflections $(I>$ $\left.3 \sigma(I), 2 \theta \leq 46^{\circ}\right), 206$ parameters. Compound 22 crystallized in space group $P 2_{1} / n$ as a thin needle and was twinned. The twin plane involves an $a$ glide perpendicular to $c^{*}$ at $z=1 / 4$ and the twin ratio refined to $0.805(3): 0.195$. The structure contained 0.894 of the desired product and 0.106 of an impurity in which one ligand (atoms $\mathrm{C} 3-\mathrm{C} 10)$ was replaced by a coordinated $\mathrm{Cl}$ and a chloroform of crystallization $\left(\mathbf{2 4 a} \cdot \mathrm{CHCl}_{3}\right)$. The twin was modeled using intensities obtained assuming there was only one twin component and adjusting the model for intensities to be $Y(\mathbf{h})=\sum_{i} a_{i} p_{j}\left|F\left(\mathbf{h}_{i}\right)\right|^{2}$ where $a_{i}$ is the amount of the $i$ th twin component and $p_{j}$ is the fraction of the second twin component included in the collected intensity. ${ }^{72}$ The modeling of the twinned reflection data was as for compound $\mathbf{9}$, and values of $p_{\mathrm{j}}$ as a function of the $h$ reflection index are detailed under _refine_special_details in the CIF file. The overall refinement used 206 variables to define the twin overlap and 64 non- $\mathrm{H}$ atom positions (CCDC 622359).

Synthesis of $\left[\mathbf{R u}(\mathbf{C} \equiv \mathbf{C P h})_{2}(\mathbf{C O})\left(\mathbf{P P h}_{3}\right)_{3}\right]$ (25a). The compound $\left[\mathrm{RuH}(\mathrm{C} \equiv \mathrm{CPh})(\mathrm{CO})\left(\mathrm{PPh}_{3}\right)_{3}\right](\mathbf{2 6})$ was prepared as described in ref 31 , with minor variations in the spectroscopic data being observed: IR (Nujol): $2088(\mathrm{C} \equiv \mathrm{C}), 2000(\mathrm{Ru}-\mathrm{H}), 1938(\mathrm{M}-\mathrm{CO})$ $\mathrm{cm}^{-1} .{ }^{31} \mathrm{P}\left\{{ }^{1} \mathrm{H}\right\}$ NMR $(298 \mathrm{~K}, 121.5 \mathrm{MHz}): 45.03\left(\mathrm{~d},{ }^{2} J_{\mathrm{PP}}=16\right.$, axial P), 23.95 (t, ${ }^{2} J_{\mathrm{PP}}=16$, equatorial P). ${ }^{1} \mathrm{H}$ NMR $(298 \mathrm{~K}, 300$ $\mathrm{MHz}):-7.68\left(\mathrm{dt},{ }^{2} J_{\mathrm{HP}}=86,{ }^{2} J_{\mathrm{HP}}=25\right)$. Complex $26(2.30 \mathrm{~g}$, $2.26 \mathrm{mmol}$ ) was weighed into a large Schlenk flask equipped with a magnetic stirrer bar. Toluene $(200 \mathrm{~mL})$ was added, followed by ethynylbenzene $(2.0 \mathrm{~mL}, 1.80 \mathrm{~g}, 18 \mathrm{mmol})$. The mixture was stirred at room temperature, and after 2 days the infrared and ${ }^{31} \mathrm{P}\left\{{ }^{1} \mathrm{H}\right\}$ NMR spectra indicated that the reaction was complete. Yield 2.20 $\mathrm{g}(87 \%)$. IR $\left(\mathrm{C}_{6} \mathrm{H}_{6}\right): 2109(\mathrm{C} \equiv \mathrm{C}), 1972(\mathrm{CO}) \mathrm{cm}^{-1} .{ }^{31} \mathrm{P}\left\{{ }^{1} \mathrm{H}\right\} \mathrm{NMR}$ $\left(298 \mathrm{~K}, 121 \mathrm{MHz}, \mathrm{C}_{6} \mathrm{D}_{6}\right): \delta 30.16\left(\mathrm{~d},{ }^{2} J_{\mathrm{PP}}=22\right.$, axial P), $19.70(\mathrm{t}$, ${ }^{2} J_{\mathrm{PP}}=22 \mathrm{~Hz}$, equatorial P). Crystal data for $\mathbf{2 5 a} \cdot \mathrm{CH}_{2} \mathrm{Cl}_{2}: \mathrm{C}_{72} \mathrm{H}_{57}-$ $\mathrm{Cl}_{2} \mathrm{OP}_{3} \mathrm{Ru}, M_{\mathrm{w}}=1203.14$, monoclinic, $C 2 / c, a=22.9151(2) \AA, b$ $=12.9560(1) \AA, c=40.1644(6) \AA, \beta=103.6561(4)^{\circ}, V=$ 11587.2(2) $\AA,{ }^{3} Z=8, \rho_{\text {calcd }}=1.379 \mathrm{Mg} \mathrm{m}^{-3}, T=200$ (2) $\mathrm{K}$, yellow plate, 8056 independent measured reflections, R1 $=0.051$, wR2 $=0.061,3318$ absorption-corrected reflections $(I>3 \sigma(I), 2 \theta \leq$ $\left.46^{\circ}\right), 204$ parameters. The crystal used for compound 25a was small and of poor quality. Sensible constraints were used to obtain an anisotropic atom refinement using 204 variables to define 82 independent non- $\mathrm{H}$ atom positions in the $C 2 / c$ structure, which contained a $0.556(11): 0.444$ disordered $\mathrm{CH}_{2} \mathrm{Cl}_{2}$ solvent molecule (CCDC 622360).

Synthesis of $\left[\mathrm{Ru}(\mathrm{C} \equiv \mathrm{CPh})(\mathrm{HgC} \equiv \mathrm{CPh})(\mathrm{CO})_{2}\left(\mathrm{PPh}_{3}\right)_{2}\right]$ (28a). $\left[\mathrm{Ru}(\mathrm{CO})_{2}\left(\mathrm{PPh}_{3}\right)_{3}\right](\mathbf{1} ; 0.22 \mathrm{~g}, 0.23 \mathrm{mmol})$ and $\mathrm{Hg}(\mathrm{C} \equiv \mathrm{CPh})_{2}(0.10$ $\mathrm{g}, 0.25 \mathrm{mmol})$ were weighed together into a Schlenk flask equipped with a magnetic stirrer bar. Toluene $(30 \mathrm{~mL})$ was added via cannula, and the bright yellow slurry was stirred at room temperature. After 15 min the reagents had dissolved and the color had changed to pale yellow. The ${ }^{31} \mathrm{P}\left\{{ }^{1} \mathrm{H}\right\}$ NMR spectrum of the reaction mixture indicated that all of the starting material had been consumed. The solution was filtered through diatomaceous earth, the volume was reduced under dynamic vacuum to ca. $5 \mathrm{~mL}$, and the product crystallized at $-20{ }^{\circ} \mathrm{C}$ as a fine white powder, which was recrystallized from benzene as a hemisolvate. Yield: $0.16 \mathrm{~g} \mathrm{(67 \% ).}$ Anal. Found: C, 61.2; $\mathrm{H}, 3.95 ; \mathrm{P}$, 5.61. Calcd for $\mathrm{C}_{54} \mathrm{H}_{40} \mathrm{HgO}_{2} \mathrm{P}_{2-}$ $\mathrm{Ru} \cdot 0.5 \mathrm{C}_{6} \mathrm{H}_{6}: \mathrm{C}, 60.9 ; \mathrm{H}, 3.86 ; \mathrm{P}, 5.51\left(\mathrm{C}_{6} \mathrm{H}_{6}\right.$ by NMR). Mp: $110-$ $112{ }^{\circ} \mathrm{C}$ dec. ${ }^{1} \mathrm{H}$ NMR $\left(298 \mathrm{~K}, 300 \mathrm{MHz}, \mathrm{C}_{6} \mathrm{D}_{6}\right): \delta 8.22-8.16(\mathrm{~m}$, $12 \mathrm{H}), 7.57-7.54$ (dd, $2 \mathrm{H}), 7.28-7.25(\mathrm{dd}, 2 \mathrm{H}), 7.07-6.91$ (m, $24 \mathrm{H}) .{ }^{13} \mathrm{C}\left\{{ }^{1} \mathrm{H}\right\}$ NMR $\left(\mathrm{C}_{6} \mathrm{D}_{6}, 298 \mathrm{~K}, 75 \mathrm{MHz}\right): \delta 201.2,200.8$ (br, CO), 138.0 (vt, $\left.J_{\mathrm{CP}}=23, \mathrm{C}^{1}\left(\mathrm{PC}_{6} \mathrm{H}_{5}\right)\right), 134.3,134.0,132.3$, $127.2,126.9,126.8,126.6,125.6\left(\mathrm{CC}_{6} \mathrm{H}_{5}\right.$; some uncertainty in assignments due to overlap of $\mathrm{C}_{6} \mathrm{D}_{6}$ absorption), 133.69 (vt, $J_{\mathrm{CP}}=$ 
5.8, $\left.\mathrm{C}^{2,6}\left(\mathrm{PC}_{6} \mathrm{H}_{5}\right)\right), 130.2\left(\mathrm{C}^{4}\left(\mathrm{PC}_{6} \mathrm{H}_{5}\right)\right), 128.7\left(\mathrm{vt}, J_{\mathrm{PC}}=4.9\right.$, $\left.\mathrm{C}^{3,5}\left(\mathrm{PC}_{6} \mathrm{H}_{5}\right)\right] 120.4,120.0,108.9,103.3(\mathrm{C} \equiv \mathrm{C} \times 4) .{ }^{31} \mathrm{P}\left\{{ }^{1} \mathrm{H}\right\} \mathrm{NMR}$ $\left(298 \mathrm{~K}, 121 \mathrm{MHz}, \mathrm{C}_{6} \mathrm{D}_{6}\right): \delta 36.4\left(\mathrm{~s}+\mathrm{d},{ }^{2} J_{\mathrm{PHg}}=392 \mathrm{~Hz}\right) . \mathrm{IR}$ (Nujol): $2101(\mathrm{C} \equiv \mathrm{C}), 2017,1971(\mathrm{CO}) \mathrm{cm}^{-1}$. MS (APCI+): 824 $[\mathrm{M}+\mathrm{MeCN}-\mathrm{HgC} \equiv \mathrm{CPh}], 783[\mathrm{M}-\mathrm{HgC} \equiv \mathrm{CPh}]$.

Thermolysis of $\left[\mathrm{Ru}(\mathrm{C} \equiv \mathrm{CPh})(\mathrm{HgC} \equiv \mathrm{CPh})(\mathrm{CO})_{2}\left(\mathrm{PPh}_{3}\right)_{2}\right]$ (28a). A sample of $28 \mathbf{a}(20 \mathrm{mg})$ in $\mathrm{C}_{6} \mathrm{D}_{6}$ was heated to reflux; after 10 min at reflux, the compounds $\mathbf{4 b}, \mathbf{2 8 a}$, and 22 were observed by ${ }^{31} \mathrm{P}\left\{{ }^{1} \mathrm{H}\right\}$ NMR spectroscopy in a 1:5:1 ratio; the infrared spectrum was consistent with the presence of this mixture. Further reflux (30 min total) resulted in visible deposition of elemental mercury and the complete disappearance of the resonance for $[\mathrm{Ru}(\mathrm{C} \equiv \mathrm{CPh})$ $\left.(\mathrm{HgC} \equiv \mathrm{CPh})(\mathrm{CO})_{2}\left(\mathrm{PPh}_{3}\right)_{2}\right]$; a 1:1 mixture of $\mathbf{4 b}$ and $\mathbf{2 2}$ was observed along with several minor unidentified resonances in the range $\delta 41-32$.

Synthesis of $\left[\mathbf{R u}\left\{\eta^{4}-\mathrm{O}=\mathrm{CC}_{4} \mathbf{P h}_{2}(\mathrm{C} \equiv \mathbf{C P h})_{2}\right\}(\mathbf{C O})_{2}\left(\mathrm{PPh}_{3}\right)\right]$ (29). Pale yellow $2(0.30 \mathrm{~g}, 0.42 \mathrm{mmol})$ and diphenylbutadiyne $(0.26 \mathrm{~g}$, $1.27 \mathrm{mmol}$ ) were weighed into a small Schlenk flask equipped with a magnetic stirrer bar. Toluene $(50 \mathrm{~mL})$ was added, and the solution was stirred and heated at reflux for $12 \mathrm{~h}$, resulting in a color change from pale yellow to orange-brown and the appearance in the infrared spectrum of metal carbonyl bands at 2021 and $1969 \mathrm{~cm}^{-1}$ (cf. 2018, $\left.1967 \mathrm{~cm}^{-16}\right)$; the ${ }^{31} \mathrm{P}\left\{{ }^{1} \mathrm{H}\right\}$ NMR spectrum of the crude mixture contained resonances at $\delta 41.8$ (29; approximate integral 1), 39.8 $(0.3), 36.4(9 ; 0.4)$, and $-4.7\left(1\right.$; free $\left.\mathrm{PPh}_{3}\right)$. The reaction mixture was filtered to remove a small amount of pale solid, and the solvent was removed under reduced pressure. Diethyl ether was added to the flask to wash the insoluble product, which was isolated by filtration as an orange powder. The supernatant diethyl ether contained some 9, identified by ${ }^{31} \mathrm{P}\left\{{ }^{1} \mathrm{H}\right\}$ NMR and infrared spectroscopy. The unit cell of $\mathbf{2 9}$ was determined crystallographically and was the same as that reported (reported values ${ }^{6}$ in parentheses): $a=12.65$ (12.66) $\AA, b=13.35$ (13.30) $\AA, c=24.51$ (24.55) $\AA, \beta=102.1$ (101.9) $)^{\circ}$. Yield: 0.23 g, 64\%. Anal. Found: C, 74.80; H, 4.31; P, 3.86. Calcd for $\mathrm{C}_{53} \mathrm{H}_{35} \mathrm{O}_{3} \mathrm{PRu}$ : C, 74.72; $\mathrm{H}$, 4.14; P, 3.64. Mp: $195-198{ }^{\circ} \mathrm{C} .{ }^{1} \mathrm{H}$ NMR $(298 \mathrm{~K}, 300 \mathrm{MHz}$, $\left.\mathrm{C}_{6} \mathrm{D}_{6}\right): \delta_{\mathrm{H}} 7.4-6.8\left(\mathrm{~m}, \mathrm{C}_{6} \mathrm{H}_{5}\right) .{ }^{13} \mathrm{C}\left\{{ }^{1} \mathrm{H}\right\}$ NMR $(298 \mathrm{~K}, 75 \mathrm{MHz}$, $\left.\mathrm{C}_{6} \mathrm{D}_{6}\right): \delta_{\mathrm{C}} 201.4\left(\mathrm{~d},{ }^{2} J_{\mathrm{PC}}=12, \mathrm{RuCO}\right), 168.3(\mathrm{~s}, \mathrm{CO}), 133.3(\mathrm{~d}$, $\left.J_{\mathrm{PC}}=11.0, \mathrm{C}^{2,6}\left(\mathrm{PC}_{6} \mathrm{H}_{5}\right)\right), 131.9\left(\mathrm{~d}, J_{\mathrm{PC}}=46.8, \mathrm{C}^{1}\left(\mathrm{PC}_{6} \mathrm{H}_{5}\right)\right), 130.1$ $\left(\mathrm{d},{ }^{4} J_{\mathrm{PC}}=2.7, \mathrm{C}^{4}\left(\mathrm{PC}_{6} \mathrm{H}_{5}\right)\right), \mathrm{C}^{3,5}\left(\mathrm{PC}_{6} \mathrm{H}_{5}\right)$ obscured by $\mathrm{C}_{6} \mathrm{D}_{6}$ resonance, 132.1, 129.7, $128.6\left(\mathrm{C}^{2,3,5,6}\left(\mathrm{CC}_{6} \mathrm{H}_{5}\right)\right.$; fourth resonance obscured by $\left.\mathrm{C}_{6} \mathrm{D}_{6}\right), 134.0,128.9,128.8,126.9\left(\mathrm{C}^{1,4}\left(\mathrm{CC}_{6} \mathrm{H}_{5}\right)\right) .96 .0$, $85.6(C=C \mathrm{CO}), 83.3,82.9(\mathrm{C} \equiv \mathrm{C})$. N.B.: some ambiguity in assignments due to overlap of $\mathrm{C}_{6} \mathrm{D}_{6}$ resonance. ${ }^{31} \mathrm{P}\left\{{ }^{1} \mathrm{H}\right\}$ NMR $(298$ $\mathrm{K}, 121 \mathrm{MHz}$ ): in $\mathrm{C}_{6} \mathrm{D}_{6}, \delta_{\mathrm{P}} 41.9$; in $\mathrm{CDCl}_{3}, \delta_{\mathrm{P}} 43.77$. IR: in Nujol, $2202(\mathrm{C} \equiv \mathrm{C}), 2019,1969(\mathrm{RuCO}), 1621(\mathrm{C}=\mathrm{O}) \mathrm{cm}^{-1}$; in $\mathrm{CH}_{2} \mathrm{Cl}_{2}$, 2246 (CC), 2026, 1975 (RuCO), 1612 (CO) $\mathrm{cm}^{-1}$; in toluene, 2021, 1969 (RuCO) $\mathrm{cm}^{-1}$. N.B.: previously reported data (Nujol) include two (sic) absorptions at $1928.2 \mathrm{vs}$ and $1928.2 \mathrm{w} \mathrm{cm}^{-1}$. These were absent from the spectra we obtained and presumably represent a further product. MS (ESI+): $852\left[\mathrm{M}^{+}\right], 263\left[\mathrm{HPPh}_{3}\right]$.

Attempted Synthesis of $\left[\mathrm{Ru}\left(\eta^{2}-\mathrm{Me}_{3} \mathrm{SiC} \equiv \mathrm{CC} \equiv \mathrm{CSiMe}_{3}\right)(\mathrm{CO})_{2^{-}}\right.$ $\left.\left(\mathbf{P P h}_{3}\right)_{2}\right]$ (4c). (a) The ${ }^{31} \mathrm{P}$ NMR spectrum of a solution of [Ru$\left.(\mathrm{CO})_{2}\left(\mathrm{PPh}_{3}\right)_{3}\right]\left(\mathbf{1} ; 30 \mathrm{mg}, 0.032 \mathrm{mmol}, \delta_{\mathrm{P}}\left(\mathrm{C}_{6} \mathrm{D}_{6}\right)\right.$ 58.03) and $\mathrm{Me}_{3} \mathrm{SiC} \equiv \mathrm{CC} \equiv \mathrm{CSiMe}_{3}(8 \mathrm{mg}, 0.05 \mathrm{mmol})$ in $d_{8}$-toluene was measured and found to comprise a 5:1 mixture of $\left[\mathrm{Ru}(\mathrm{CO})_{2}\left(\mathrm{PPh}_{3}\right)_{3}\right]$ $\left(\delta_{\mathrm{P}} 50.73\right)$ and $\mathbf{4 c}\left(\delta_{\mathrm{P}} 45.68\right)$. Heating this mixture to reflux for 15 min resulted in the formation of a 1:1 mixture of $\mathbf{1}$ and $\mathbf{2}\left(\delta_{\mathrm{P}} 56.69\right)$ in addition to a broadened peak due to $\mathrm{PPh}_{3}$. The spectra remained invariant on continued heating (2-12 h). After 3 days the spectrum revealed primarily 2 and $\mathrm{PPh}_{3}$.

(b) A mixture of the ethylene complex $\mathrm{Ru}\left(\mathrm{C}_{2} \mathrm{H}_{4}\right)(\mathrm{CO})_{2}\left(\mathrm{PPh}_{3}\right)_{2}$ (20; $30 \mathrm{mg}, 0.042 \mathrm{mmol}, \delta_{\mathrm{P}}\left(\mathrm{C}_{6} \mathrm{D}_{6}\right)$ 58.03) and $\mathrm{Me}_{3} \mathrm{SiC} \equiv \mathrm{CC} \equiv$ $\mathrm{CSiMe}_{3}(8 \mathrm{mg}, 0.05 \mathrm{mmol})$ in $d_{6}$-benzene was stirred for $10 \mathrm{~min}$. The ${ }^{31} \mathrm{P}\left\{{ }^{1} \mathrm{H}\right\}$ NMR spectrum of the solution comprised a 2:1 mixture

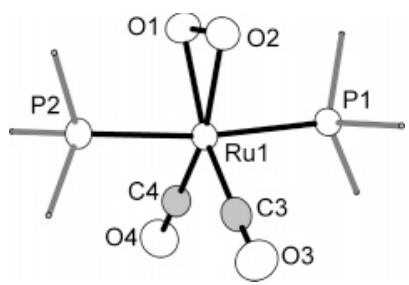

Figure 5. Molecular geometry of $\mathbf{2 1}$ in the crystal (50\% displacement ellipsoids, phenyl groups omitted) Selected bond lengths ( $)$ and angles (deg): Ru1-P1 = 2.3707(6), Ru1-P2 = 2.3797(7), $\mathrm{Ru} 1-\mathrm{O} 1=2.0281(17), \mathrm{Ru} 1-\mathrm{O} 2=2.0360(17), \mathrm{Ru} 1-\mathrm{C} 3=1.890-$ (3), $\mathrm{Ru} 1-\mathrm{C} 4=1.886(2), \mathrm{O} 1-\mathrm{O} 2=1.462(3), \mathrm{O} 3-\mathrm{C} 3=1.145-$ (3), $\mathrm{O} 4-\mathrm{C} 4=1.142(3) ; \mathrm{O} 1-\mathrm{Ru} 1-\mathrm{O} 2=42.16(8), \mathrm{O} 1-\mathrm{Ru} 1-\mathrm{C} 3$ $=153.88(10), \mathrm{O} 2-\mathrm{Ru} 1-\mathrm{C} 3=111.99(10), \mathrm{O} 1-\mathrm{Ru} 1-\mathrm{C} 4=$ 112.16(9), O2-Ru1-C4 = 153.97(9), C3-Ru1-C4 = 93.89(10), $\mathrm{Ru} 1-\mathrm{O} 1-\mathrm{O} 2=69.21(10), \mathrm{O} 1-\mathrm{O} 2-\mathrm{Ru} 1=68.63(9), \mathrm{Ru} 1-\mathrm{C} 3-$ $\mathrm{O} 3=178.0(2), \mathrm{Ru} 1-\mathrm{C} 4-\mathrm{O} 4=177.4(2)$.

of 20 and $\mathbf{4 c}$. Heating this mixture under reflux (sealed tube) for $12 \mathrm{~h}$ provided a mixture comprising 20 (125), 2 (75), 1 (21), 4c (35), and various minor peaks.

(c) A mixture of the ethylene complex $\mathrm{Ru}\left(\mathrm{C}_{2} \mathrm{H}_{4}\right)(\mathrm{CO})_{2}\left(\mathrm{PPh}_{3}\right)_{2}$ (20; $30 \mathrm{mg}, 0.042 \mathrm{mmol}, \delta_{\mathrm{P}}\left(\mathrm{C}_{6} \mathrm{D}_{6}\right)$ 58.03) and $\mathrm{Me}_{3} \mathrm{SiC} \equiv \mathrm{CC} \equiv$ $\mathrm{CSiMe}_{3}(8 \mathrm{mg}, 0.05 \mathrm{mmol})$ in $d_{6}$-benzene was stirred for $10 \mathrm{~min}$. The sample was then degassed by two freeze/thaw cycles in vacuo and allowed to reach equilibrium by stirring for $10 \mathrm{~min}$. The cycle was repeated, providing a solution comprising a 1:4 mixture of 20 and $\mathbf{4 c}$.

(d) Nitrogen was gently bubbled through a solution of the ethylene complex $\mathrm{Ru}\left(\mathrm{C}_{2} \mathrm{H}_{4}\right)(\mathrm{CO})_{2}\left(\mathrm{PPh}_{3}\right)_{2}(\mathbf{2 0} ; 30 \mathrm{mg}, 0.042 \mathrm{mmol}$, $\left.\delta_{\mathrm{P}}\left(\mathrm{C}_{6} \mathrm{D}_{6}\right) 58.03\right)$ and $\mathrm{Me}_{3} \mathrm{SiC} \equiv \mathrm{CC} \equiv \mathrm{CSiMe}_{3}(8 \mathrm{mg}, 0.05 \mathrm{mmol})$ in $d_{6}$-benzene for $20 \mathrm{~min}$ to provide a 1:20 mixture of $\mathbf{2 0}$ and $\mathbf{4 c}$. The solvent was removed, and limited spectroscopic data were acquired for the resulting pale yellow powder, which also contained small amounts of $\mathrm{Me}_{3} \mathrm{SiCCCCSiMe}_{3}\left(\delta_{\mathrm{H}}\left(\mathrm{C}_{6} \mathrm{D}_{6}\right) 0.03\right) .{ }^{1} \mathrm{H}$ NMR $\left(298 \mathrm{~K}, 300 \mathrm{MHz}, \mathrm{C}_{6} \mathrm{D}_{6}\right):-0.04,0.24\left(\mathrm{~s} \times 2,9 \mathrm{H} \times 2, \mathrm{SiCH}_{3}\right)$, 7.00-7.16 (m, 18H, H $\left.{ }^{3-5}\left(\mathrm{C}_{6} \mathrm{H}_{5}\right)\right)$, 7.77-7.85 (m, $\left.12 \mathrm{H}, \mathrm{H}^{2,6}\left(\mathrm{C}_{6} \mathrm{H}_{5}\right)\right)$. ${ }^{13} \mathrm{C}\left\{{ }^{1} \mathrm{H}\right\}$ NMR $(298,75 \mathrm{MHz}$, only limited data due to solution instability, $\left.\mathrm{C}_{6} \mathrm{D}_{6}\right)$ : $\delta_{\mathrm{C}} 134.8\left(\mathrm{vt}, J_{\mathrm{PC}}=5.7, \mathrm{C}^{2,6}\left(\mathrm{PC}_{6} \mathrm{H}_{5}\right)\right), 134.6(\mathrm{vt}$, $\left.J_{\mathrm{PC}}=5.6, \mathrm{C}^{3,5}\left(\mathrm{PC}_{6} \mathrm{H}_{5}\right)\right), 132.1\left(\mathrm{vt}, \mathrm{C}^{1}\left(\mathrm{PC}_{6} \mathrm{H}_{5}\right)\right), 130.4\left(\mathrm{C}^{4}\left(\mathrm{PC}_{6} \mathrm{H}_{5}\right)\right)$, 0.79, $-0.69\left(\mathrm{SiCH}_{3}\right)$. IR: in Nujol, $2116(\mathrm{C} \equiv \mathrm{C}), 1976,1906(\mathrm{CO})$ $\mathrm{cm}^{-1}$; in $\mathrm{C}_{6} \mathrm{D}_{6}, 2067(\mathrm{C} \equiv \mathrm{C}), 1974,1911(\mathrm{CO}) \mathrm{cm}^{-1}$. Satisfactory elemental microanalytical data were not obtained.

Crystal Structure Determination of $\left[\mathrm{Ru}\left(\mathrm{O}_{2}\right)(\mathrm{CO})_{2}\left(\mathrm{PPh}_{3}\right)_{2}\right]$ (21). This complex was prepared according to the method of Roper. ${ }^{4}$ The room-temperature crystal structure has been previously reported; ${ }^{20}$ however, we have acquired a higher quality data set at $200 \mathrm{~K}$ leading to a more precise refinement model (Figure 5). Crystal data for 21: $\mathrm{C}_{38} \mathrm{H}_{30} \mathrm{O}_{4} \mathrm{P}_{2} \mathrm{Ru}, M_{\mathrm{w}}=713.67$, triclinic, $P \overline{1}$ (No. 2), $a=9.7315(1) \AA, b=9.8696(2) \AA, c=17.2896(5) \AA, a=$ $96.0096(11)^{\circ}, \beta=91.8165(15)^{\circ}, \gamma=92.1069(15)^{\circ}, V=1649.30$ (6) $\AA,{ }^{3} Z=2, \rho_{\text {calcd }}=1.437 \mathrm{Mg} \mathrm{m}^{-3}, T=200(2) \mathrm{K}, 7547$ independent measured reflections, $\mathrm{R} 1=0.029$, wR2 $=0.029,5370$ absorption-corrected reflections $\left(I>3 \sigma(I), 2 \theta \leq 54.94^{\circ}\right), 407$ parameters (CCDC 622357).

Crystal Structure Determination of $[\mathbf{R u}(\eta-\mathrm{PhC} \equiv \mathrm{CC} \equiv \mathrm{CPh})-$ $\left.(\mathbf{C O})_{2}\left(\mathbf{P P h}_{3}\right)_{2}\right](\mathbf{4 b})$. This complex was prepared according to the method of Alcock et al. ${ }^{2}$ Crystal data for $\mathbf{4} \mathbf{b} \cdot \mathrm{C}_{6} \mathrm{H}_{6}: \mathrm{C}_{60} \mathrm{H}_{46} \mathrm{O}_{2} \mathrm{P}_{2-}$ $\mathrm{Ru}, M_{\mathrm{w}}=962.04$, triclinic, $P \overline{1}$ (No. 2), $a=11.1877(2) \AA, b=$ 12.2839(2) $\AA, c=17.9333(4) \AA, \alpha=92.913(1)^{\circ}, \beta=100.133$ $(1)^{\circ}, \gamma=101.607(1)^{\circ}, V=2367.0(1) \AA,{ }^{3} Z=2, \rho_{\text {calcd }}=1.350$ $\mathrm{Mg} \mathrm{m}^{-3}, T=200(2) \mathrm{K}$, yellow block, 8316 independent measured reflections, $\mathrm{R} 1=0.066$, wR2 $=0.102,6003$ absorption-corrected reflections $\left(I>3 \sigma(I), 2 \theta \leq 55^{\circ}\right), 228$ parameters. Compound $\mathbf{4 b}$ was refined as a 1:1 disordered structure in space group $P$ 1. Diffuse scattering along lines parallel to $b^{*}$ implied the structure was ordered 
in layers perpendicular to $b^{*}$. Packing considerations show that layers take up one of two inversion-related options, which order all atoms except those of one triphenylphosphine. The choice between the two options for these atoms is determined by the choice between inversion-related options for an adjacent layer. Sensible constraints were used to define 115 independent non- $\mathrm{H}$ atom positions using 228 variables and to obtain a successful anisotropic atom refinement (CCDC 622356).
Supporting Information Available: CIF files giving crystallographic details for $\mathbf{4 b}, \mathbf{9}, \mathbf{2 1}, \mathbf{2 2}$, and 25a. This material is available free of charge via the Internet at http://pubs.acs.org. These files are also available from the Cambridge Crystallographic Database: 4b (CCDC 622356), 9 (CCDC 622358), 21 (CCDC 622357), 22 (CCDC 622359), and 25a (CCDC 622360).

OM060888L 